NBER WORKING PAPER SERIES

\title{
THE FIRST OF THE MONTH EFFECT: CONSUMER BEHAVIOR AND STORE RESPONSES
}

\author{
Justine S. Hastings \\ Ebonya L. Washington \\ Working Paper 14578 \\ http://www.nber.org/papers/w14578 \\ NATIONAL BUREAU OF ECONOMIC RESEARCH \\ 1050 Massachusetts Avenue \\ Cambridge, MA 02138 \\ December 2008
}

We thank Joseph Altonji, Steven Berry, Keith Chen, Raj Chetty, Judy Chevalier, Nada Eissa, Tim Guinnane, Patrick Kline, Camille Landais, Jesse Shapiro, Sharon Oster and seminar participants at Boston University, Brown University, IIES, the NBER TAPES Conference, University of California at Berkeley, University of Chicago GSB and the Yale Industrial Organization lunch for valuable input. Lydia Ashton and Alexander Torgovitsky provided excellent research assistance. We gratefully acknowledge funding from the Yale University Institution for Social and Policy Studies. All remaining errors are ours. The views expressed herein are those of the author(s) and do not necessarily reflect the views of the National Bureau of Economic Research.

NBER working papers are circulated for discussion and comment purposes. They have not been peerreviewed or been subject to the review by the NBER Board of Directors that accompanies official NBER publications.

(C) 2008 by Justine S. Hastings and Ebonya L. Washington. All rights reserved. Short sections of text, not to exceed two paragraphs, may be quoted without explicit permission provided that full credit, including $\odot$ notice, is given to the source. 
The First of the Month Effect: Consumer Behavior and Store Responses

Justine S. Hastings and Ebonya L. Washington

NBER Working Paper No. 14578

December 2008

JEL No. H0,H2,H31,H32,L1

\begin{abstract}
$\underline{\text { ABSTRACT }}$
Previous research has used survey and diary data to carefully document that Food Stamp recipients decrease their expenditures and consumption of food throughout the benefit month, the beginning of which is defined by the date on which benefits are distributed. The reliance on survey and diary data has meant that researchers could not test two rational hypotheses for why food consumption cycles. Using detailed grocery store scanner data we ask 1) whether cycling is due to a desire for variation in foods consumed that leads to substitution across product quality within the month and 2) whether cycling is driven by countercyclical pricing by grocery retailers. We find support for neither of these hypotheses. We find that the decrease in food expenditures is largely driven by reductions in food quantity, not quality, and that prices for foods purchased by benefit households vary pro-cyclically with demand implying that benefit households could save money by delaying their food purchases until later in the month. The price effects are small relative to demand changes and relative to impacts found for other subsidy programs such as EITC, suggesting that most of the benefits accrue to the intended recipients particularly in product categories and stores where benefit recipients represent a small fraction of overall demand. We conclude by concurring with previous literature that food cycling behavior is most likely due to short-run impatience.
\end{abstract}

Justine S. Hastings

Yale University

P.O. Box 208264

New Haven, CT 06520-8264

and NBER

justine.hastings@yale.edu

Ebonya L. Washington

Yale University

Box 8264

37 Hillhouse, Room 2

New Haven, CT 06520

and NBER

ebonya.washington@yale.edu 


\section{Introduction}

There is a growing line of empirical literature demonstrating the sensitivity of the timing of household purchases to the timing of the receipt of income. Stephens $(2003,2006)$ finds evidence of a purchasing cycle in two distinct populations: social security recipients in the United States and paycheck recipients in the United Kingdom, both of whom receive checks monthly. In samples of both groups he finds that spending on instantaneous consumption, which he defines as fresh food, food away from home and entertainment, increases following income receipt. Stephens concludes that he finds evidence in violation of the permanent income hypothesis. Other researchers, such as Huffman and Barenstein (2005) who examine the same United Kingdom data as Stephens (2006), push the interpretation further, concluding that the cycling patterns in purchases constitute real world evidence of short run impatience or quasi-hyperbolic discounting. ${ }^{1}$

Researchers investigating the prevalence of short run impatience have paid particular attention to populations receiving government benefits, presumably because of the group's policy relevance; utility losses suffered by recipients due to impatience could be inexpensively undone through public policy. ${ }^{2}$ Wilde and Ranney (2000) and Shapiro (2005) use survey data to document, not only that Food Stamp recipients buy relatively more food at the beginning of their Food Stamp month, but more importantly that they consume relatively more calories as well. Shapiro (2005) estimates that calorie intake decreases by 0.45 percent per day within the Food Stamp month. He presents evidence against food spoilage, theft, strategic considerations vis-à-vis other family members and community members, or naïveté driving the results. He interprets this as evidence of short run impatience. His policy prescription is for localities to divide Food Stamp distribution into smaller, more frequent payments to each household.

\footnotetext{
${ }^{1}$ Laibson (1997) develops the notion of quasi-hyperblic discounting in which individuals have distinct short and long run time preferences and evaluate trade offs with a present bias. The majority of empirically support for impatience has been found in laboratory settings (Frederick et. al, 2002).

${ }^{2}$ For example Dobkin and Puller (2007) find that that SSI and DI recipients see an increase in drug related hospitalizations and mortality at the beginning of their payment month. Foley (2008) shows that financially motivated crime is higher at the end of the Food Stamp/TANF payment month.
} 
In this paper we consider two alternative explanations for the benefit household food consumption cycle that could not be tested using survey data. First, recipients may have a preference for variation in the quantity and quality of food consumed, providing a rational explanation for expenditure and consumption patterns over the course of the month. Because of data limitations Shapiro (2005) presents only indirect evidence against the desire for a few "feast" days. He points to survey data demonstrating cycling in Food Stamp recipients' hypothetical willingness to accept a smaller immediate payment in place of a larger payment in the future. As the month goes on recipients are more willing to accept the smaller payment. He interprets this finding as evidence that the marginal utility of income (to buy food) is not constant, but rather increases throughout the month, suggesting that benefit households do not desire this variance in food consumption. Households who show the greatest increases in marginal utility are the most likely to report food shortfalls at the end of the month. Second, cycling in purchasing behavior could also be consistent with rational behavior if, as in previous literature (e.g., Warner and Barsky 1995, MacDonald, 2000, Chevalier, Kashyap and Rossi, 2003) prices decline at times of peak demand and therefore groceries are less expensive at the beginning of the month. Prior research relying on survey or diary data cannot address store pricing response to demand cycles, and lack the detail to test for substitution across product quality within grocery category over the course of the month.

Access to two years of item-level scanner data from three Nevada stores belonging to a national supermarket chain allows us to present direct evidence on the relevance of these alternative hypotheses. We first document, consistent with previous literature, that benefit recipients-defined as customers who ever purchase with Food Stamps or cash welfare assistance currency-do relatively more of their food shopping at the beginning of the month - defined as the date on which benefits are distributed. We find a sharp decrease in benefit households' food expenditures of more than 20 percent from the first to the second week of the month. Expenditures continue to decline less steeply through the remainder of the month. The decline from the first to the fourth week of the month is 34 percent. This result is robust across the three stores, which differ in their share of purchases by benefit households. Further the result is robust across products from 
storable to perishable items. We see no such cycle in food expenditures amongst store patrons who do not receive benefits, whether low or high income.

Second, we examine to what extent the decrease in food expenditures is driven by changes in quantities versus changes in the quality of food purchased. We find overwhelming evidence in favor of the former. In fact point estimates suggest that quantity reductions can explain the full decrease in food expenditures. From week one to week four benefit households reduce their quantities purchased by 35 percent. Quality reductions are much smaller. From week one to week four benefit households increase their relative (to non-benefit households) propensity to buy generic by one percent and decrease their relative propensity to buy premium by two percent. Benefit households also exhibit a small increase (one percent) in their relative propensity to purchase sale items. Thus we find no evidence that the food spending cycle is driven by a desire for variation in food in food products consumed throughout the month.

While some states stagger benefit delivery, in Nevada Food Stamps and cash benefits are distributed to all recipients on the same day. Thus each month grocery stores face a large and predictable increase in demand for goods most heavily purchased by benefit recipients. Finally, we explore the store's pricing response to this demand shift. We do not find evidence of counter-cyclical pricing, but instead find that the increase in aggregate demand induced by benefit delivery results in food price increases. While the pricing response is small—prices fall 3 percent as quantities purchased fall 34 percentthe fact that prices move pro-cyclically with demand rules out the desire to purchase food when it is relatively cheaper as an explanation for the food purchasing cycle. The fact that prices rise, even slightly, with demand provides additional support for impatience as the best explanation of the purchasing behavior. Even if households have non-convex preferences, they would do better to shift their expenditure peak to a later point in the month.

These findings add further support to the hypothesis that food stamp recipients display impatience. They also suggest that the bulk of food stamp subsidies accrue to the 
intended recipients, particularly in markets and products where subsidy recipients represent a lower overall percentage of demand. The relatively small price effects stand in contrast to estimates of incidence in other subsidy programs, such as EITC, where recipients make up a large fraction of the market and their behavior is likely to have a large impact on equilibrium market prices (e.g. labor supply and wages in Rothstein (2008) and used car prices in Adams, Einav and Levin (2008)).

One key limitation of our study is that we only have data for one grocery store per neighborhood. If low income shoppers' choice of food retailer is correlated with timing within the month then our purchasing pattern results will be biased. However, our expenditure results are of a similar magnitude to Shapiro (2005) who relies on survey data which is not prone to such bias. Further, our results are unchanged when we limit consideration to those shoppers who make purchases during both the first and the last two weeks within the month. A second concern stemming from our use of grocery data concerns the generalizeability of our pricing results. We know that grocery chains are far more likely to locate in low poverty neighborhoods (Chung and Myers, 1999). However, across the nation 83 percent of Food Stamps are cashed in super markets and 50 percent of Food Stamp recipients spend their benefits exclusively in super markets (Cole and Lee, 2005). Thus our pricing results are relevant for the majority of Food Stamp recipients, but likely not as relevant for the recipients who are least well off. We present both our expenditure and pricing results in detail, after describing our data in the following section.

\section{Data}

Previous investigations of the monthly food expenditure/consumption cycle have relied on household survey data. Such data have been extremely valuable in allowing researchers to carefully document cycling amongst benefit-receiving populations. However, because household survey data do not provide the full menu of products from which households are able to choose nor the monthly variation in price of products, chosen or unchosen, survey data do not allow for the investigation of two possible causes 
of such cycling: 1) a desire to consume a variety of food products across the month and 2) a response to variation in food prices across the month. We are fortunate to have access to grocery store scanner data that will allow us to investigate both of these possibilities.

Our scanner data cover transactions at three focal stores in a national grocery chain over the 26 month period from January 2006 to February 2008. The data include an observation for each item purchased, detailing the quantity, price and any discounts applied. While our supermarket chain carries both food and non-food items such as would be found in a drug store, in keeping with previous literature, we analyze only food purchases. Our data set includes an observation for each food item scanned at the register during our 26 month period. Each item is uniquely identified by its Universal Product Code (UPC), an identifier which is specific to the product and size of container where applicable (e.g. extra large Red Delicious apples, or General Mills Cheerios Cereal $18 \mathrm{Oz}$ Box). There are thousands of UPCs for food items. The store groups the UPCs into higher order classifications. For example, Red Delicious Apples are a subset of apples which are a subset of the category fresh produce. For tractability, when we present results by food type, we will do so by these 38 most macro categories, of which Fresh Produce is one and Cereal and Breakfast is another.

For each scanned item, the data also record the form of payment which can include among others cash, credit, debit and most importantly for our purposes currency from the social programs, Food Stamps, cash welfare and WIC. Finally each record includes a household loyalty card identifier. We use the loyalty card number and payment information to identify benefit recipients. In particular, we categorize a loyalty card number as belonging to a welfare recipient if that loyalty card was associated with any purchases settled with currency from social programs over the 26 month period. We will refer to such loyalty card holders as "benefit households" from here forward. ${ }^{3}$

\footnotetext{
${ }^{3}$ We tried a couple of different measures including defining the welfare households over one year period instead of over the entire period. The results are robust to changes in this definition.
} 
We analyze purchases at three stores located in the state of Nevada. We focus on Nevada because Food Stamp and cash assistance benefits are delivered to all recipients on the first day of the month in that state. ${ }^{4}$ This concentrated benefit delivery schedule is important for our ability to identify the start of the benefit recipient income month and thus to be able to chart the pattern of expenditures throughout that month.

In Nevada both Food Stamps and cash assistance are distributed electronically to a benefits card that works like a debit card. Benefits do not expire; they may be carried over from month to month. Nevada's cash assistance program is less generous than the national average. In 2002 the maximum benefit for a family of three with no income was \$348 compared to a national mean of $\$ 413$ and median of $\$ 390$ (Rowe and Russell, 2002). Even including Food Stamp benefits — which are determined according to a single national formula which takes cash benefits into account-Nevada residence's maximum benefit level is below the national median (United States House of Representatives, Committee on Ways and Means, 2004).

Within Nevada, we select our three focal stores based on the demographic characteristics of their patrons. In particular we select stores in which a relatively large share of food purchases (more than 15 percent) were made by benefit recipient households. We further seek variation in percent of purchases made by benefit households so that we can shed light not only on how store pricing responds to benefit households' monthly expenditure cycle, but further how that response varies with the stores' share of purchases by benefit households. (Food prices are set weekly and can vary by store.) We have therefore chosen stores in which 15 percent (Store 1), 28 percent (Store 2) and 47 percent (Store 3) of purchases are made by benefit recipients. The stores are all located in zip codes in which Latinos and families in poverty are overrepresented (by two to three times) and educational attainment levels are lower than national averages. In all neighborhoods, our

\footnotetext{
${ }^{4}$ WIC benefits are distributed upon request. Our results are robust to excluding WIC recipients from the benefit household category.
} 
focal store faces competition from both small ethnic grocers as well as larger chain retailers. $^{5}$

Table 1 presents summary statistics of household expenditures for benefit and nonbenefit households over the twenty-six month period. The first three columns show expenditure patterns over the course of the month for all stores pooled together, and each subsequent set of three columns presents statistics for an individual store. Twenty-seven percent of all purchases are made by benefit-receiving households across the three stores. Looking at percent of purchases by time of the month, we see that benefit households' share of store purchases falls by eight percentage points overall, by between four and ten percentage points by store. Benefit households spend an average of $\$ 42$ dollars per week on food items at our supermarket, while non-benefit households spend slightly less per week (\$31.23). Previewing our results we see that average weekly expenditures fall between the first and second half of the month for benefit households, but remains constant for non-benefit households.

The remaining rows of the table examine purchasing patterns by purchase type. We divide all products into three quality categories: generic, mainstream, and premium. Our categorization is based on product descriptions provided to us by the grocery chain. We code as premium any product that is so categorized in the store's description. We code as generic, non-premium items that are marketed under the store's private-label. Any premium private-label products are classified as premium. Mainstream is the residual category capturing all items that are neither generic nor premium. Table 1 indicates that the share of purchases devoted to each product category is quite similar for benefit and non-benefit households. About 55 percent of purchases for both groups are of mainstream products, about 10 percent generic and the remainder premium. Dividing products simply according to whether they are on promotion (on sale) or not, we see that 59 percent of products purchases by the poor are on sale, compared with 57 percent of purchases by the

\footnotetext{
${ }^{5}$ Zip code demographic data are drawn from the 2000 census using the American Fact finder website. Competition data from www.switchboard.com.
} 
non-poor. These patterns are quite consistent across stores and across the month. ${ }^{6}$ Benefit households are only slightly more likely than other households to purchase generics or sale items. Further, that these relative patterns are consistent across the month previews our results that benefit households do not substitute across product types over the course of the month.

However, it is not the case, that benefit and non-benefit households are buying the exact same products, as Figure 1 demonstrates. The figure displays the share of purchases, across the three stores, made by benefit households, by the 38 food categories. The darker bars indicate the share of purchases in the first two weeks of the month. The lighter bars correspond to the second two weeks. While across all products, benefit households make 27 percent of purchases, we see that there is considerable variation by category. Benefit households are relatively less likely to purchase alcohol, fresh produce, frozen fruits and fresh bread. On the other hand, these families are relatively more likely to purchase rice and beans, prepared foods, meat, commercial sweet baked goods, flour/sugar/corn meal and frozen juices and vegetables. Within products, benefit households account for a larger share of revenue in the first two weeks than the second two weeks of the month. This is true for all products which previews our confirmation of the cycling expenditure result. We provide our results formally in the next section.

\section{Regression Analysis of Expenditures}

Table 2 documents monthly food expenditure patterns for benefit recipient and nonrecipient households. The table cells report coefficients from regressions of the following form:

$$
Y_{i t s}=\text { ben }_{i} * \text { week }_{t} \beta^{\prime}+\text { week }_{t} \delta^{\prime}+h_{i} \lambda^{\prime}+s_{s} \eta^{\prime}+\varepsilon_{i t s}
$$

\footnotetext{
${ }^{6}$ The scanner data include information on markdowns and discounts for each item. If an item is purchased and a discount is posted at the register, we consider that item to be 'on sale'.
} 
where $Y_{i t s}$ is the $\log$ of total expenditures for household $i$ in week $t$ at store $s, b e n_{i}$ is an indicator for whether household $i$ is classified as a benefit household, week $k_{t}$ is a row vector of dummies for each 7 day period beginning at the first of each month (week of the pay month dummies, where we exclude from the sample the days past the $28^{\text {th }}$ day of the month), $h_{i}$ is a row vector of household id fixed-effects, $s_{s}$ is a row vector of store fixedeffects. The first week of the pay month and its interaction with the benefit household indicator are omitted so that each coefficient (multiplied by 100) is the percentage decline in total expenditures relative to the first week. Each column of Table 2 presents the coefficients for $\beta$ and $\delta$. Standard errors, clustered at the household level, are reported in parentheses. The first column presents results for all stores pooled together, while the subsequent columns present results by store.

Turning to the first column, we see that benefit households decrease their grocery purchases throughout the month. Relative to non-benefit receiving households, benefit households' total purchases (first row) decline by 20.53 percent from week one to week two and continue to decline, though not as steeply, as we move from week three to week four, when the reduction is 33.52 percent relative to week one. In contrast, non-benefit households exhibit almost no decline in expenditures over the course of the month. The coefficients on the week dummies are generally an order of magnitude smaller than the coefficients on the interactions indicating a much smaller decrease (off a smaller mean) in purchases across the month for non recipient purchasers.

Our results are consistent with Wilde and Ranney (2000) and Shapiro (2005) who document food spending decreases across the month for low-income households. The magnitude of the decline we demonstrate is similar to Shapiro (2005) who focuses exclusively on Food Stamp recipients and finds a decrease in the market value of purchased food of 20 percent from the first to the $28^{\text {th }}$ day of the month. Shapiro's market value of food is not measured directly through prices, however. The Nationwide Food Consumption Survey, whose data he uses, assigns this value based on the food the household reports that it consumes. That our results are slightly greater in magnitude is not surprising given that we focus on a population who receive both their Food Stamp 
and their cash welfare benefits on the exact same day of the month. The similarity of our results to those of Shapiro (2005) lends credence to our claim that despite our focus on only one retail outlet per community we are capturing representative grocery purchases of benefit households.

The food expenditure cycle we identify is consistent across the three stores, the remaining columns of Table 2 show. In each store benefit households' relative decrease in expenditures from week one to week two is 15 to 20 percent, with smaller decreases in subsequent weeks. In week 4, expenditures have fallen 20 to 30 percent, compared to week one, across the three outlets. The similarity in food expenditure cycle amongst the three different populations of low-income shoppers not only demonstrates the robustness of the result, but further indicates that a comparison of pricing behavior amongst the three focal stores is likely to tease out the stores' response to variation in fluctuation in aggregate demand induced by the relative sizes of their benefit-receiving population.

In Table 3 we demonstrate that the food expenditure cycle is also robust to food category. The table presents the coefficients and standard errors for $\beta$ from regressions of the form (1) run separately for each food category in our sample. The results show that the decline in benefit recipients' expenditures over the monthly cycle is remarkably consistent across food categories. In fact, there is no category of food for which there is not a significant decline in relative purchases by benefit-recipient households from the first to the fourth week of the month. In only one category—frozen fruits—is that decline not significant at the one percent level.

The robustness of the result across food type suggests a violation of the permanent income hypothesis. We group food categories into four types of goods to reinforce this point. Looking at food items by groupings, we first see that relative purchases of storable items fall by 10 to 25 percent from week one to week four. But of course precisely because the purchasing and consumption of these items can be decoupled temporally, the cycle of purchase of storable items may not constitute a violation of the permanent income hypothesis. Likewise we might not be surprised to see that relative purchases of 
splurge items falls by 11 to 18 percent from week one to week four. The idea that households may indulge in "feast" days at the beginning of the month is one explanation that has been put forth to explain the purchasing cycle that we consider later in this section. However, there is no rational theory under which we should see cycling amongst perishable staples, like produce, meat and bread. But in fact we see the largest relative declines in meat purchases. In general we see that amongst perishable items the relative decline in purchases is between six and 29 percent suggesting that that benefit households are not smoothing expenditures and consumption over the predictable monthly income cycle.

Finally, it is interesting to note that we see a purchasing cycle even in those products that cannot be purchased using Food Stamps: namely alcohol and tobacco products (of course these items can be purchased either with cash benefits or with cash itself.) Benefit households decrease their relative purchases of alcohol and tobacco by five percent from week one to week two and by nine percent from week one to week four.

Table 4 employs information on household income to investigate if the identified decline in expenditures generalizes to low-income households who may be budget constrained but do not depend on the monthly benefits cycle for income. We use estimated household income data that the supermarket chain collects for a sample of loyalty card holders, and add interactions between weekly dummies and income quartiles to equation (1). The first specification in Table 4 (columns 1 and 2) repeats the base specification in Table 2 for the subsample of households with demographic data, and confirms the same expenditure decline is present in this subsample. The second specification (columns 3 and 4) add interactions between income quartiles and weekly effects among non-benefit households. Coefficients on these interactions, even for the least well off quartile, are an order of magnitude smaller than our focal benefit households * week coefficients. Our results indicate that the purchasing pattern is particular to benefit households.

There are at least two threats to the identification strategy we use to document how food spending responds to income payments. First, the increase in food expenditure at the 
beginning of the month may be driven by other events on the calendar, and not the receipt of payment. A concern for this possibility leads us to augment our model of the form (1) with controls for month, time trend, holiday dummies and gasoline prices. ${ }^{7}$ These additions do not change our results of Tables 2 and 3 because of the structure of the monthly pay cycle. Few events will occur consistently on the first each month.

A second concern is that our results are driven by selection. Perhaps the type of household who purchases food at one of our supermarkets at the beginning of the month is distinct from the type of household who purchases food at the supermarket at month's end. If this is the case, then we need to consider two possibilities. First, in weeks when we do not observe a household shopping at one of our focal stores, the household could be purchasing food at another establishment. Second, it is possible in the weeks that a household does not appear in our data they are not purchasing any food at all. To ensure that the alternative shopping venue form of selection is not driving our results, we run models of the form of (1) limiting our sample to households who purchase in a focal store in both the first and second two weeks of the month. Results are robust to this change in sample. To investigate whether variation in purchasing on the extensive margin is biasing our results we run linear probability models of the decision to purchase in a particular week $^{8}$ and then recover the total (not conditional on expenditures greater than zero) derivative of expenditures with respect to benefit weeks by following the procedure laid out by McDonald and Moffitt (1980). ${ }^{9}$ We find that the probability of purchase for benefit households declines by eight percentage points (off of a mean of 49 percent) from the first to the fourth week of the month. The decline is less than one percentage point (off of a mean of 40 percent) for non-benefit households. The unconditional decline in expenditures over the same time period is $\$ 13.64$ (off of a mean of \$21.17) for benefit households and only $\$ 0.14$ (off of a mean of $\$ 12.34$ ) for non-benefit households. Thus

\footnotetext{
${ }^{7}$ Gicheva, Hastings and Villas-Boas (2007) show sensitivity in grocery purchases to sharp changes in gasoline prices.

${ }^{8}$ For tractability and because of the possibility of household relocation, we eliminate household-weeks that occur in months in which the household made no purchases in a focal store.

${ }^{9}$ Specifically, let $\mathrm{E}(\mathrm{y})$ be the expected value of $\mathrm{y}, \mathrm{E}\left(\mathrm{y}^{*}\right)$ be the expected value of $\mathrm{y}$, conditional on $\mathrm{y}$ being greater than zero and $\mathrm{F}(\mathrm{z})$ be the probability that $\mathrm{y}$ is greater than zero. Then $\mathrm{E}(\mathrm{y})=\mathrm{F}(\mathrm{z})^{*} \mathrm{E}\left(\mathrm{y}^{*}\right)$ and $\mathrm{dEy} / \mathrm{dx}=\mathrm{F}(\mathrm{z}) \mathrm{dEy} * / \mathrm{dx}+\mathrm{Ey} *(\mathrm{dF}(\mathrm{z}) / \mathrm{dx}$.
} 
this exercise supports the conclusion that there is a monthly benefits grocery expenditure cycle.

In Table 5 we decompose this $\$ 13.64$ decrease into decreases due to changes in purchases on the extensive and intensive margins. We find that across all goods changes in purchase conditional on purchasing accounts for about 65 percent of the total decrease for benefit households. But while relatively few households discontinue all grocery store purchases by month's end, more households will discontinue all purchases within a particular category of goods. In fact, across good type we find that an average of only 18 percent of declines is due to declines on the intensive margin.

Our results thus far provide a robust replication of findings in previous literature: benefitreceiving households' grocery expenditures fall across the month. Because we have replicated this finding with scanner data as opposed to survey data, we can now explore patterns in household expenditures over the monthly cycle that would not be possible to investigate with data on expenditures from the Consumer Expenditure Survey, for example. We can examine if benefit households display further non-standard income effects. For instance, do they feel relatively wealthy at the beginning of the month, substituting towards premium and brand-name products and away from generics (Allenby and Rossi (1991))? Given that they do not smooth consumption, do they shift towards inferior goods or become more sensitive to promotional items as the month proceeds and their relative income level decreases in an attempt to stretch their marginal dollars further (Gicheva, Hastings and Villas-Boas (2007))? Our scanner data allow us to move beyond what previous literature has been able to do with diary data. We are able to decompose this change in expenditures to examine to what extent cycling is driven by changes in quantity versus quality of food items purchased. This distinction is important. One untested hypothesis for the monthly expenditure cycle is that households have a desire for a variety of products throughout the month. If the decrease in expenditures is driven by quality adjustments, households moving from the purchase of high to low quality products throughout the month, that would lend support to this theory. On the other hand 
if the decrease in expenditures is driven primarily through quantity adjustments, then that would be further evidence of impatience on the part of benefit recipients.

In Table 6 we examine how quantity purchased changes throughout the month. Because different items have different sizes, we report all quantities in ounces. We have sizes for approximately 90 percent of the items purchased so the sample size decreases slightly as we move to Table 6. The specification remains of the form (1), but the dependent variable is now log weekly quantity purchased (measured in total ounces). The coefficients show the decline in total number of ounces purchased by household $i$ in week $t$ at store $s$ as we move from the first to the last week of the month. The first column shows coefficients from a regression pooling data from all stores with store fixed-effects, while the next three columns show regression results run separately for each store. The results of the first column demonstrate that benefit recipients exhibit a large relative decline in total quantity purchased across the month. The results are of a similar magnitude to the results for log expenditures in Table 2. Across all food types, low income households reduce their relative quantity purchased by 24 percent from week one to week two and by 35 percent from week one to week four. Recall that these same households reduce total expenditures by 34 percent across the four weeks. This suggests that the decline in expenditures is coming solely from a decline in quantity purchased, rather than in price savings from substitution towards less expensive products. Once again our main week effects are an order of magnitude smaller than our interactions indicating a small decline in quantities purchased across the month for households who do not receive benefits. And once again our results are robust across stores, the remaining columns of the table indicate. In all three stores benefit recipients see a fall in quantity purchased from week one to week four that is within three percentage points of the fall in expenditures over the same time period.

This decrease in quantities purchased amongst benefit recipients is quite robust to type of food, the results of Table 7 demonstrate. In all categories point estimates indicate a decline in relative quantities purchased from week one to week four. That decline is insignificant in only two of 38 categories: tobacco products and frozen juices. And in 
another two-- frozen fruits and frozen desserts--that decline is only significant at the 5 percent level. In the remaining 34 of 38 categories covering storable, perishable, splurge and uncovered (by Food Stamps) products, we see highly significant reductions, on the order of 10 to 25 percent, in quantities purchased from week one to week four. Once again the results are robust to the inclusion of additional controls and to limiting the sample to households who purchase at month's beginning and end. Thus Tables 6 and 7 show that benefit households reduce food expenditures throughout the month largely through reductions in quantities purchased.

In Tables 8 and 9 we examine measures of the quality margin. We examine how families substitute among mainstream, generic and premium products and between sale and nonsale over the course of the month, using regressions of the form (1) where the dependent variable is either the quantity-weighted fraction of purchases for household $i$ in week $t$ from store $s$ that are classified as 'generic', 'premium' or on sale. Because the extent to which generic (premium/sale) products are available differs by product and over time, we control for share of products available to consumer $i$ at store $s$ in week $t$ in category $k$ that are generic (premium/sale). Classic income effects may lead households to substitute away from normal and luxury goods towards inferior goods as income drops, and this has been proposed as a reason for disparate cross-price elasticities between private label and brand name products (Allenby and Rossi 1991). While benefits households are not experiencing a change in permanent income over the course of the month, it is interesting to compare their substitution patterns across products to those identified elsewhere in response to changes in permanent income.

The first column of the Generic Panel of Table 8 indicates that across all food categories, benefit receiving households show a small increase in their share of generic products purchased throughout the month. In week two their relative purchases of generic products increase a half of a percent (compared to week one) off of a mean of 15 percent. The increase in weeks three and four over week one are 8/10 of a percent and a full percent respectively. The one percentage point increase across the month is true for all three stores, the remaining columns demonstrate. The small negative week four main effect 
coefficient indicates that non-welfare households very slightly decrease their share of generic products purchased in week four compared to week one. (This decrease amongst non-benefit households is driven by Stores 2 and 3 only.)

As Table 9A shows, this substitution to cheaper generic brands amongst the benefit receiving households is driven by significant movements to generic in just 8 of 34 food categories: cookies, soft beverages, cereal, soup, rice and beans, cheese, refrigerated juice and drinks and meat. Across these eight categories the increase in benefit households' relative share generic increases by one to three percent in week four over week one. Benefit households significantly decrease their purchases across the month in just one food category: commercial fresh bread. There is no significant shift away or toward generic products across the month by low income households in the remaining 25 categories. Thus Table 9 demonstrates that substitution toward less expensive generic products accounts for only a small portion of benefit recipients' monthly decrease in food expenditures.

The results of the Premium panel of Table 8 reinforce the notion that benefit-receiving households decrease food expenditures by reducing quantity more than by reducing quality. In this panel the dependent variable is an indicator for whether the item purchased is a premium label. Complementing the small increase in generic products purchased, we see here a small decrease in premium products purchased across the month. Benefit recipient households' share of premium products decreases by one percent from week one to week two and by two percent from week one to week four. In the aggregate, the mean share premium is 24 percent for benefit receiving households and 25 percent for non-benefit receiving households. The positive week effects indicate that non-benefit households increase their share of premium products purchased as the month moves towards its end. Both the decrease in premium purchases for recipient households and the increase for non-recipient households are robust across stores.

The aggregate substitution away from premium products for benefit recipients is driven, once again, by only a few food types. Benefit receiving households significantly decrease 
share premium of salty snacks, meat, commercial fresh bread and refrigerated juice and drinks. The extent of substitution ranges from less than a percent decrease from week one to week four for salty snacks to a four percent decrease for commercial fresh bread across that time period. Benefit households significantly increase their share of premium purchases on only one food category: flour/sugar/corn meal. This increase is only significant at the 5 percent level. For the remainder of products, we see no substitution between premium and non-premium across the month. Thus the premium specification provides further evidence that benefit recipients decrease their food expenditures throughout the month primarily by reducing quantities rather than substituting across foods of various qualities.

The final panel of Table 8 examines whether benefit households become more sensitive to promotional items as the month proceeds. Gicheva, Hastings, and Villas-Boas (2007) use scanner data to examine how grocery expenditures shift in response to changes in permanent income generated by gasoline price spikes. They find that households respond by substituting towards promotional items, increasing the fraction of items purchased on sale by 10 to 50 percent when gasoline prices double, saving approximately 5 to 10 percent on grocery expenditures. Table 8 shows that low income household exhibit only a small substitution toward promotional products as the month wanes. Their relative fraction of promotional items increases by one percent from week 1 to week 4 . The week dummies, of a similar magnitude, indicate that non-benefit households increase their purchases of sales items by less than one percent. Thus for benefit-receiving households the total increase in propensity to purchase sale items is less than two percent from week one to week 4 . This result is driven by only 13 food categories, as shown in Table 9C.

The results of this section indicate that benefit recipients show a steep drop in food expenditures over the course of the month. Grocery expenditures in week four are thirty percent smaller than those in week one. The results are true for both storable and perishable items and thus constitute a violation of the permanent income hypothesis. Our results are consistent with those found in prior literature using survey and diary data on household food expenditures. Authors of earlier work have theorized that the purchase 
cycling is due to irrationality or impatience on the part of low-income households. Two alternative explanations for these purchasing patterns could not be explored with survey data. The first is that benefit households enjoy a "feast day" at the start of the month, purchasing premium products at the beginning of the month, and substituting towards inferior products towards month's end. However, using detailed scanner data we have found no evidence to support this hypothesis. We find that the vast majority of the expenditure declines result from declines in quantities purchased, rather than substitution to lower quality or even sale items. ${ }^{10}$

The second untested hypothesis is that the purchasing cycle can be rationalized by changes in stores prices. We test this second hypothesis in the next section.

\section{Regression Analysis of Retail Response to Cyclical Demand}

In this section, we examine the firms' response to benefit households' predictable demand cycles. There are three possible responses. First, retailers may price countercyclically, decreasing prices during periods of peak demand. This strategy has been documented in several settings, including retail grocery where both MacDonald (2000) and Chevalier, Kashyap and Rossi (2003) find large decreases in the price of food items during their high demand season. MacDonald (2005) shows that across 48 products with seasonal fluctuation in demand, prices fall an average of 8 percent as demand rises by 199 percent. Chevalier, Kashyap and Rossi (2003) demonstrate that the price of tuna drops 13 percent during lent and that the prices of snack crackers and cheese fall by more than 10 percent during the Christmas season. The authors argue that their findings are consistent with a loss leader model of pricing in which stores compete for customers

\footnotetext{
${ }^{10}$ We tested several alternative measures of product quality in addition to generic/premium categories and sale items. In particular we generated a quantity-weighted income index for each UPC of the income of households who purchased it over our sample period. This measure might capture items that wealthier people are more likely to purchase, and thus may be higher quality. We also constructed a z-score of price (per standardized quantity unit such as ounce) within product categories and sub-categories to measure the relative expense of a product. We estimated (1) using these alternative measures of quality as the dependent variable. We find statistically significant but economically very small declines in these measures of quality for benefit household purchases over the course of the month. Thus the results from these alternative specifications are very similar to those found for fraction generic vs. premium and fraction purchased on sale.
} 
through advertised prices on items of high relative demand. However, Nevo and Hatzitaskos (2005) decompose the seasonal price paid reductions into substitution (to less expensive brands) and price reduction effects. They find that the substitution effects are the larger of the two, which is less consistent with the loss leader model. While the loss leader model makes no predictions for pricing during increases in aggregate demand for all products, which we document occur monthly in our three grocery stores, Warner and Barsky (1995) show that countercyclical pricing may be optimal if consumer demand elasticity increases in periods of peak demand due to economies of scale in search. Consumers who make one large shopping trip at the start of the month, search more for the lowest price retailer for their large purchases at the start of the month than they do for their small purchases at the end of the month. At the start of the month consumers have more expenditures and items over which to reap the gains to finding the lowest price store. This makes demand more elastic during peak-demand, generating counter-cyclical retailer pricing. Such counter-cyclical pricing on the part of our grocery retailers would provide a rational explanation for the food purchase cycle - benefit-receiving shoppers purchase relatively more food at the beginning of the month because this is when prices are lowest. Such a finding would provide evidence against irrationality or impatience on the part of low-income households as an explanation for cycling behavior.

The second possibility is that stores do not respond to this early month increase in aggregate demand. Shapiro (2005) makes this assumption. Empirical evidence of constant within month food prices would offer no evidence against his hypothesis that monthly food consumption cycling is due to short-run impatience.

Finally, grocery retailers may pursue the traditional response to an increase in demand or decrease in demand elasticity: They may raise prices cyclically as demand rises. Cyclical pricing would mean that benefit households could increase welfare by delaying their purchases until later in the month when prices fall. For example, Adams, Einav and Levin (2008) show that demand for sub-prime used auto loans increase by 30 percent at the time of EITC receipt and required cash down-payments increase in response by 20 percent, implying that liquidity-constrained purchasers could do better to slightly delay 
their car purchase after receiving their EITC check. Hence cyclical demand accompanied by cyclical pricing would provide additional support for short-run impatience on the part of welfare recipient households as an explanation for their food purchase behavior.

In order to examine store pricing behavior, and whether benefit recipients are responding to prices rationally or whether they could save money from altering purchase timing, we create a price index that measures the change in the within month variation in the cost of benefit households' typical food basket. The price index is constructed as follows:

$$
\ln \text { price }_{t s}=\sum_{k} \omega_{k} \ln \left(p_{t s k}\right)
$$

where $\omega_{k}$ is the total share, across the three stores, that benefit-receiving households spend on product $k$ (identified by UPC) over the 26 month period; $p_{\text {tsk }}$ is the price for product $k$ at store $s$ on day $t$. Hence this price index gives the share-weighted price on each day in each store for the typical basket of groceries for a benefit household. We calculate the weights in two ways. First we calculate the weight as stated above - the share low income households spend on product $k$ over the 26 month period. Second we calculate the weights as the share that benefit households spend on product $k$ during the first week of the month for any month in our 26 month sample. This second weighting allows us to hone in on how prices vary for those goods that benefit households purchase during their most active shopping period. This weighting will allow us to answer the question of whether households could save money by altering the timing of that most active shopping period.

Table 8 presents results from regressions of the form

$$
\ln \text { price }_{t s}=\beta_{1}+\beta_{2} \text { week_ } 2_{t s}+\beta_{3} \text { week_ } 3_{t s}+\beta_{4} w e e k_{-} 4_{t s}+\varepsilon_{t s}
$$

where week $i$ is an indicator for the week of the month that each store-day observation falls into. We exclude days after the $28^{\text {th }}$ day of the month, so the first week becomes the 
excluded category. The top panel of the table uses the basket based on purchases of benefit-receiving households regardless of timing. The bottom panel uses the basket based solely on purchases made during the first week of each month.

The first four columns of Table 10 provide price results for our three focal grocery stores. The coefficients in the first column of the top panel indicate that the basket of goods purchased by benefit recipient households is two percent less expensive in week two compared to week 1 . The basket's price falls to 2.7 percent less expensive in week 4 , compared to week 1 . The bottom panel of the table examines changes in the price of the benefit households' week 1 basket. The first column of this panel indicates that the magnitude of the cyclical movement in the price of this basket of goods is even larger than the movement in price for the whole month basket. The week 1 to week 4 price change is 3.3 percent. This finding suggests the opportunity for welfare gains on the part of benefit households by substituting intertemporally and/or across products in their food purchase behavior.

Returning to the first panel to examine the store by store changes in the price of the benefit household food basket, we see that the magnitude of the price decline increases with the percentage of store's merchandise purchased by benefit recipients. Store 1, at which recipients account for 15 percent of purchases, reduces the prices of the food basket 1.7 percent in week four compared to week one. At Store 2 with 28 percent of purchases made by benefit recipients the figure is 3 percent; at Store 3 with 47 percent of purchases made by benefit households the number rises to 3.5 percent. The difference between the four week price change at Store 1 and Store 3 is statistically significant. The pattern of greater price changes with a larger benefit-receiving population is retained as we shift our focus to results for the week 1 basket, shown in the bottom panel of the table. Stores with a higher fraction of purchases by benefit households face larger fluctuations in aggregate demand.

Further evidence that the variation in the price of the benefit households' food bundle is driven by fluctuations in aggregate demand comes from the remaining columns of Table 
10 where we run models of the form of (3) for Nevada stores at which a much smaller share - 3 to 6 percent-of purchases are made by benefit households. The benefit households who shop at these stores show a similar decline in relative expenditures (we find in untabled regressions), but clearly their food purchase cycling has a small impact on fluctuations in aggregate demand. While the benefit households' food bundle is less expensive as the month continues, point estimates indicate that at these low poverty stores the decline in price is less than one percent from week one to week four and is statistically insignificant. The result is robust for all stores collectively and for each store individually. As for the stores with a higher share of benefit customers, when we move to the week 1 basket we see larger (in magnitude) price changes. The decrease from week one to week four for all stores remains under one percent but is now statistically significant. This result is driven by a one percent drop at Store 1 and its statistical significance is not robust across stores. Thus the results of Table 10 suggest that our high poverty focal stores increase their prices cyclically in response to changes in aggregate demand.

A final specification check is presented in Table 11. This table presents regression results for four stores in Colorado and California with similar concentrations of benefit household patrons, but where benefits are distributed over the first ten days of the month instead of just on the first of the month ${ }^{11}$. In these stores, we would expect the decline in expenditures to start after the first 10 to 17 days, and to perhaps be smaller in magnitude since during the first part of the month, some recipients are in their first food-stamp week while others are in their last. We would expect the price response for these stores to be delayed a week as well and perhaps smaller in magnitude if the results generalize outside of the Nevada stores we have examined so far. The results in Table 11 show exactly this pattern. The first column of results present OLS estimates from our base specification (1), where the dependent variable is log weekly expenditures. We find that expenditures decline significantly beginning in the third week of the month for benefit households,

\footnotetext{
${ }^{11}$ In both states Food Stamps are distributed to each recipient on a date between the first and the tenth of the month, based on the last digit of the recipient's social security number. Cash benefits are delivered, again as a function of social security number, between the first and the third of the month in Colorado and in Los Angeles, where our California stores are located.
} 
after most recipients have past their first week after receiving benefits. The second column presents OLS results from (3) for the Colorado and California stores. As expected, we find a significant price decline that begins in week 3 instead of week 2 . Again, the price response is small in magnitude, but statistically significant.

In Figure 2, we explore how the high poverty stores' pricing varies across product categories. To do so we construct price indexes based solely on the products in a particular category at our core set of Nevada high-poverty stores (recall that within each broad category like "Fresh Produce" there are many individual products). The figure shows a scatter plot of the change in quantity purchased by benefit households from week one to week four against the change in product pricing across the three stores over the same time period. The figure displays results using the weights generated by benefit household purchases during any first week of any month throughout our 26 month time period. The point estimates using both basket definitions are shown in Appendix Tables 1 and 2.

The figure is notable for the positive slope of the points. As quantity purchased increases, so does price. Across categories, the correlation between within-month quantity changes and change in price is 0.45 . For instance, products such as meat and rice and beans for which quantities purchased fell by more than 20 percent across the month also see some of the greatest (in magnitude) price changes across the same time period. Products for which there is less variation in benefit households' demand such as canned fruits, frozen juices, in store fresh bread and alcohol and tobacco, see less price change. The figure provides further evidence that the cyclical price changes are driven by cyclical increases in product demand.

Thus our pricing results reveal that the prices of food items purchased by benefit households fall by about three percent from the first to the fourth week of the month. Relative to the 30 percent decrease in quantities purchased by this population over the same time period, the price fluctuations are small. Our average benefit household spends a little over $\$ 200$ per month at our grocery store. A savings of three percent is only $\$ 6$. Nonetheless are findings are notable for two reasons. First, our pricing results indicate 
that benefit households could stretch their food dollar a little further by shifting food purchases to later in the month. In the previous section we find that benefit households could lower their food spending by shifting purchases across products (from premium to generic or from non-sale to sale items). Taken together our findings suggest that benefit households are fairly inert in their substitution patterns. These households could smooth consumption and minimize the costs of their food basket through intertemporal and/or cross product substitution.

Second, our pricing results speak to the question of whether the observed food expenditure cycle amongst low-income households should be interpreted as short term impatience on the part of these households. While countercyclical pricing would have provided an alternative explanation for the purchasing patterns, our results of slightly pro-cyclical food pricing provide additional support for impatience as explanation. Furthermore, while one alternative explanation for monthly expenditure patterns is nonconvex preferences, adding in evidence on prices shows that even if benefit households prefer lumpy expenditures which vary in quantity or quality of food consumed across the month given their budget constraint, they would be significantly better off to shift their consumption peak slightly to take advantage of lower prices at periods of lower aggregated demand.

\section{Conclusion}

Using detailed scanner data from a national grocery retailer we document a food expenditure cycle amongst benefit recipients in the state of Nevada. Households, who receive Food Stamps and/or cash welfare, increase their food expenditures in the first week following benefit distribution. The decline in food expenditures from week 1 to week 2 is 20 percent amongst these households, with smaller additional declines across the remainder of the month. By week four, food expenditures, relative to non-benefit recipients, have fallen 34 percent from expenditures in week one. We identify no such expenditure cycle for non-benefit recipients. Our findings for benefit households are 
robust across stores at which benefit recipients purchase a varying share of the food items. Results are also robust across food categories, from perishable to storable, and thus constitute a violation of the permanent income hypothesis. Our results are consistent with those of Wilde and Ranney (2000) and Shapiro (2005) who use expenditure survey data to document a food spending cycle amongst Food Stamp recipients. The latter author concludes that this pattern is evidence of hyperbolic discounting or short-run impatience on the part of benefit recipients.

Our scanner data allow us to explore two alternative explanations that could not be tested using survey data. First, we consider the possibility that benefit recipients desire variety in their food consumption and thus purchase splurge items at the beginning of the month and shift to lower cost items at month's end. Second, we investigate the store's pricing response to understand whether the expenditure cycle is a rational response to decreased food prices early in the month.

We find no support for either of these alternative hypotheses. Benefit households do little cross-product substitution as the month progresses. The decreased expenditure at month's end can be entirely accounted for by a change in quantities purchased. Point estimates indicate that the relative ounces of food product purchased by benefit households fall 35 percent from week four to week one. While benefit households are only one percent more likely to purchase generic items and about two percent less likely to purchase premium items over the same time period. The relative tendency for benefit households to purchase sale items also increases only slightly (one percent) throughout the month. Thus there is no evidence that benefit households food expenditure cycle is driven by a desire for higher quality feast days upon check receipt.

We further find no evidence that the purchasing cycle is spawned by lower prices during the high demand early month period. We compute a price index for the basket of food goods consumed by benefit-recipient households. The price of this basket falls about 3 percent from week one to week four. While this price decrease is small relative to the change in quantities purchased, it provides strong evidence against the expenditure cycle 
being driven by a desire to purchase food items at lower prices. In fact even had we found evidence that benefit households substitute across quality within the month, or even if benefit households define splurge days as increases in only quantity, the fact that the greater expenditures occur during the time of highest prices, would mean that the substitution patterns could not be interpreted as rational behavior. Thus both our food quality/quantity results and our pricing results lend support to the notion that food expenditure cycling is due to short-run impatience on the part of low-income households. Evidence of short run impatience has also been found in other populations in labor market behavior (Della Vigna and Paserman, 2001), health club plan choice (Della Vigna and Malmendier, 2006), and credit card usage (Laibson, Repetto and Tobacmanm 2003).

Shapiro (2005) makes a policy prescription based on benefit recipients' impatience. He proposes that Food Stamp benefits which are currently distributed to each household monthly in all states, be distributed more frequently, in smaller amounts. Our store pricing results suggest a second policy innovation should be considered if the goal is to improve the welfare of benefit recipients. While in Nevada and eight other states Food Stamp benefits are distributed to all recipients on a single day, in other states benefit delivery is staggered, generally across a week or two. ${ }^{12}$ Staggering the delivery of Food Stamp and cash benefits across the full month would eliminate the large swings in aggregate demand amongst benefit recipients and would likely curtail the variation in the price of their food basket. Staggering is low cost given that benefits are now delivered electronically. However, what can not be inferred based on this investigation is at what price level the food basket would settle under staggering. Would the equilibrium food prices that results be closer to the lower cost end of the month price or the slightly higher cost beginning of the month price? Calculating the equilibrium prices over the course of the month and the welfare implications for staggering benefits would require estimating the parameters of individual demand for grocer products (i.e does food stamp receipt increase demand, make it less elastic, or both), as well as the pricing decision of a multi product firm that prices both national and private label products.

\footnotetext{
${ }^{12}$ Email from the Department of Agriculture dated February 26, 2007.
} 
Secondly, we do not know about the generalizeability of our pricing results. While we have focused on a grocery chain, we know that chains generally locate in lower poverty neighborhoods. Chung and Myers (1999) show that 89 percent of chain grocery stores in the Minneapolis-St. Paul are located in neighborhoods of less than 10 percent poverty. While the majority of Food Stamps are cashed in supermarkets, in order to understand how benefit recipients in the poorest neighborhoods would be affected by staggering, it is important to understand how non chain food retailers respond to the first of the month increase in aggregate demand. 


\section{$\underline{\text { References }}$}

Adams, William, Liran Einav and Jonathan Levin (2008). "Liquidity Constraints and Imperfect Information in Subprime Lending.” American Economic Review, forthcoming.

Allenby, Greg and Peter Rossi (1991). "Quality Perceptions and Asymmetric Switching Between Brands.” Marketing Science, 10, 3, 185-204.

Chevalier, Judith, Anil Kasyhap and Peter Rossi (2003). "Why Don’t Prices Rise During Periods of Peak Demand? Evidence from Scanner Data.” American Economic Review, 93, 1, 15-37.

Chanjin, Chung and Samuel L. Myers, Jr. (1999). "Do the Poor Pay More for Food? An Analysis of Grocery Store Availability and Food Price Disparities." The Journal of Consumer Affairs, 33, 2, 276-296.

Cole, Nancy and Ellie Lee (2005). Analysis of EBT Benefit Redemption Patterns: Methods for Obtaining, Preparing and Analyzing the Data. Cambridge, MA: Abt Associates."

Della Vigna, Stefano and Ulrike Malmendier (2006). "Paying Not to Go to the Gym." American Economic Review, 96, 694-719.

Della Vigna, Stefano and M. Daniele Paserman (2005). “Job Search and Impatience.” Journal of Labor Economics, 23, 527-588.

Dobkin, Carlos and Steve Puller (2007). "The Effects of Government Transfers on Monthly Cycles in Drug Abuse, Hospitalization and Mortality." Journal of Public Economics, 91, 2137-2151.

Foley, C. Fritz (2008). “Welfare Payments and Crime.” Working Paper.

Frederick, Shane, George Lowenstein and Ted O’Donoghue (2002). “Time Discounting and Time Preference: A Critical Review.” Journal of Economic Literature, 40, 351-4-1.

Gicheva, Dora, Justine Hastings and Sofia Villa-Boas (2007). "Revisiting the Income Effect: Gasoline Prices and Grocery Purchases.” NBER Working Paper Number 13614.

Huffman, David and Matias Barenstein (2005). “A Monthly Struggle for Self Control? Hyperbolic Discounting, Mental Accounting and the Fall in Consumption Between Pay Days.” Working Paper.

Laibson, David (1997). “Golden Eggs and Hyperbolic Discounting.” Quarterly Journal of Economics, 112, 2, 443-477. 
Laibson, David, Andrea Repetto and Jeremy Tobacman (2003) “A Debt Puzzle.” in eds. Philippe Aghion, Roman Frydman, Joseph Stiglitz, Michael Woodford, Knowledge, Information, and Expectations in Modern Economics: In Honor of Edmund S. Phelps, Princeton: Princeton University Press, 228-266.

MacDonald, James (2000). "Demand, Information and Competition: Why Do Food Prices Fall at Seasonal Demand Peaks?” Journal of Industrial Economics, 48, 1, 27-45.

Mcdonald, John and Robert Moffit (1980). “The Use of Tobit Analysis.” Review of Economics and Statistics, 62, 2, 318-321.

Nevo, Aviv and Konstantinos Hatzitaskos (2005). "Why Does the Average Price of Tuna Fall During Lent?” NBER Working Paper Number 11572.

Rothstein, Jesse (2008). "The Unintended Consequences of Encouraging Work: Tax Incidence and the EITC.” Working paper, Princeton University.

Rowe, Gretchen and Victoria Russell (2002). The Welfare Rules Databook: State Policies as of July 2002. Washington, DC: The Urban Institute.

Shapiro, Jesse (2005). "Is There a Daily Discount Rate? Evidence from the Food Stamp Nutrition Cycle?” Journal of Public Economics, 89, 303-325.

Stephens, Mel (2003). "3 ${ }^{\text {rd }}$ of tha month: Do Social Security Recipients Smooth Consumption Between Checks?” The American Economic Review, 93, 1, 406-422.

Stephens, Mel (2006). "Paycheque Receipt and the Timing of Consumption." The Economic Journal, 116, 7, 680-701

United States House of Representatives Committee on Ways and Means (2004). 2004 Green Book: Background Material and Data on the Programs within the Jurisdiction of the Committee on Ways and Means. Washington, DC: US Government Printing Office.

Warner, Elizabeth and Robert Barsky (1995). “The Timing and Magnitude of Retail Store Markdowns: Evidence from Weekends and Holidays.” Quarterly Journal of Economics, 110, 2, 321-352.

Wilde, Parke and Christine Ranney (2000). “The Monthly Food Stamp Cycle: Shopping Frequency and Food Intake Decisions in an Endogenous Switching Regression Framework.” Journal of Agricultural Economics, 82, 200-213. 
Figure 1: Percent of Revenues Coming from Benefit Households by Food Category and Time of the Month
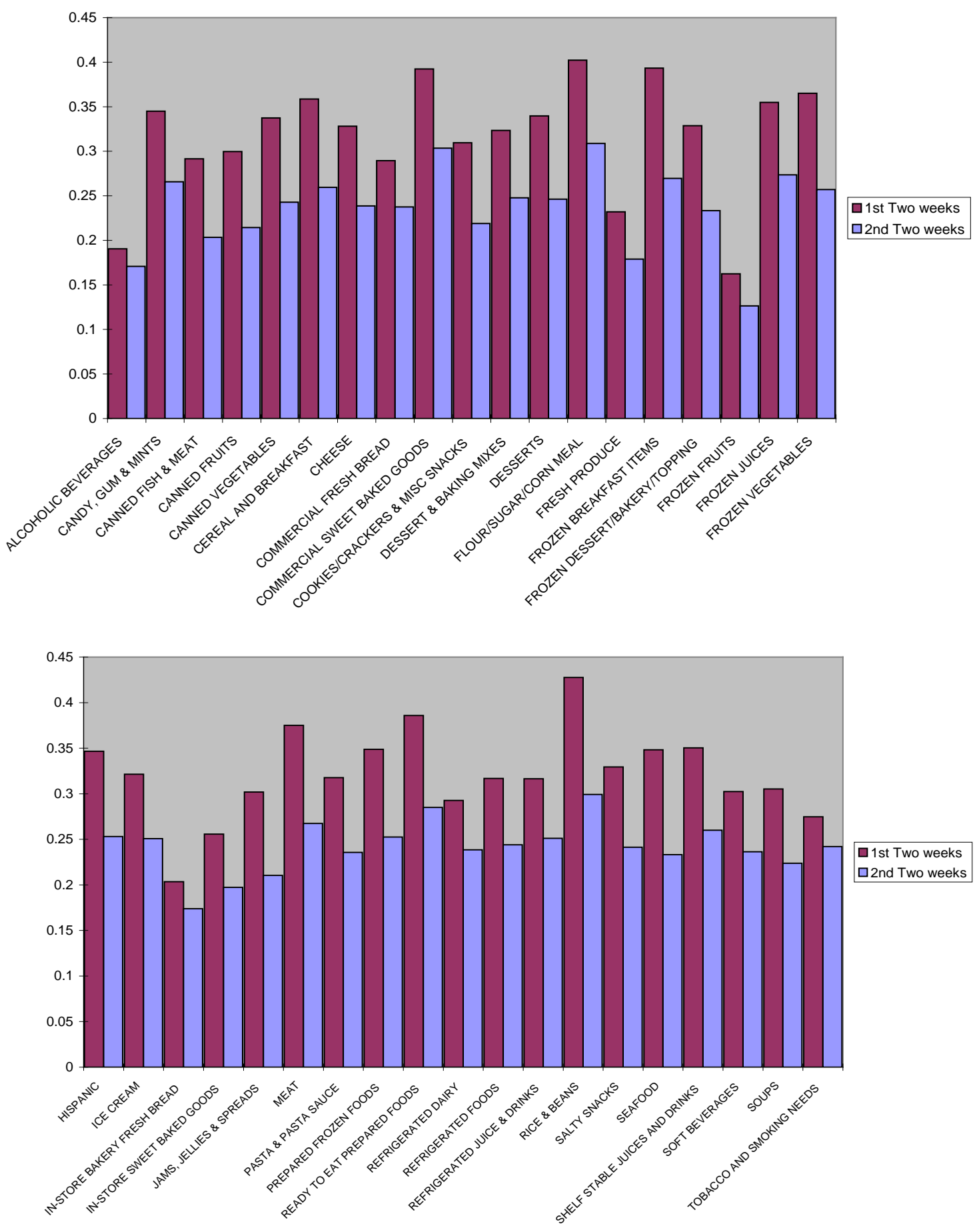
Figure 2: Scatterplot of Change in Quantities Purchased and Change in Price, by Product Category

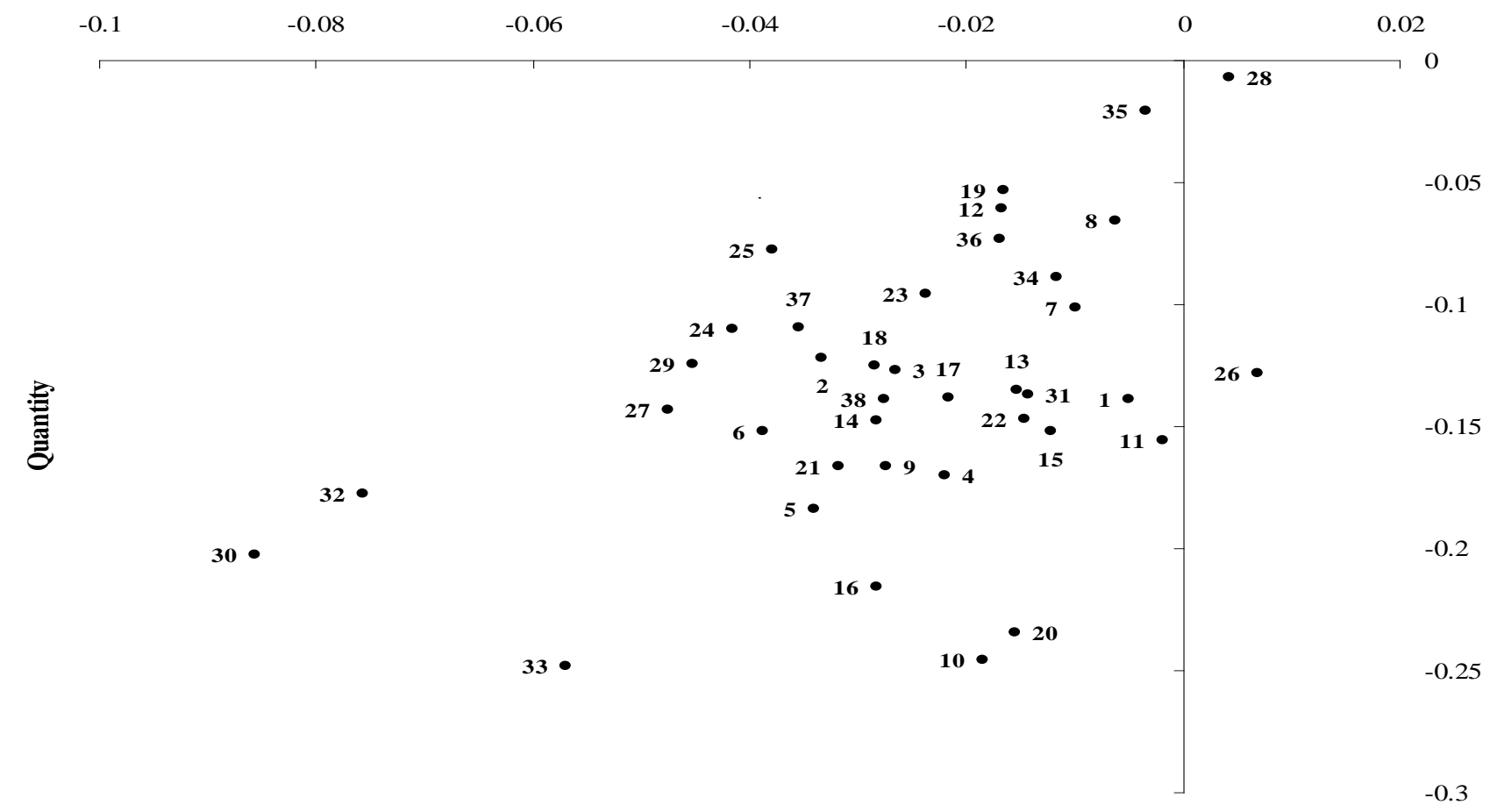

Price Index

Legend: 1. Candy, Gum and Mints; 2. Cookies/Crackers and Misc Snacks; 3. Jams, Jellies and Spreads; 4. Soft Beverages; 5. Salty Snacks; 6. Cereal and Breakfast; 7. Desserts; 8. Desserts and Baking Mixes; 9. Flour/Sugar/Corn Meal; 10. Shelf Stable Juices and Drinks; 11. Canned Vegetables; 12. Canned Fruits; 13. Canned Fish and Meat; 14. Ready-to-Eat Prepared Foods; 15. Soups; 16; Rice \& Beans; 17. Pasta and Pasta Sauce; 18. Hispanic; 19. Tobacco and Smoking Needs. 20. Refrigerated Dairy; 21. Cheese; 22. Refrigerated Foods; 23. Refrigerated Juice and Drinks; 24. Ice Cram; 25. Frozen Dessert; 15. Frozen Fruits 27. Frozen Breakfast Items; 28. Frozen Juices; 29. Frozen Vegetables; 30. Prepared Frozen Foods; 31. Fresh Produce; 32. Seafood 33. Meat 34. 35. In Store Fresh Bread 36. In Store Bakery Fresh Bread 37. Commercial Fresh Bread 38. Snacks 
Table 1: Summary Statistics

\begin{tabular}{|c|c|c|c|c|c|c|c|c|c|c|c|c|}
\hline & \multicolumn{3}{|c|}{ All } & \multicolumn{3}{|c|}{ Store 1} & \multicolumn{3}{|c|}{ Store 2} & \multicolumn{3}{|c|}{ Store 3} \\
\hline & $\begin{array}{c}\text { All } \\
\text { Weeks }\end{array}$ & $\begin{array}{c}1 \mathrm{st} \\
\text { Two } \\
\text { weeks } \\
\end{array}$ & $\begin{array}{c}\text { 2nd } \\
\text { Two } \\
\text { weeks }\end{array}$ & $\begin{array}{c}\text { All } \\
\text { Weeks }\end{array}$ & $\begin{array}{c}1 \mathrm{st} \\
\text { Two } \\
\text { weeks }\end{array}$ & $\begin{array}{c}\text { 2nd } \\
\text { Two } \\
\text { weeks }\end{array}$ & $\begin{array}{c}\text { All } \\
\text { Weeks }\end{array}$ & $\begin{array}{c}1 \text { st } \\
\text { Two } \\
\text { weeks }\end{array}$ & $\begin{array}{c}\text { 2nd } \\
\text { Two } \\
\text { weeks }\end{array}$ & $\begin{array}{c}\text { All } \\
\text { Weeks }\end{array}$ & $\begin{array}{c}\text { 1st } \\
\text { Two } \\
\text { weeks } \\
\end{array}$ & $\begin{array}{c}\text { 2nd } \\
\text { Two } \\
\text { weeks }\end{array}$ \\
\hline \multicolumn{13}{|l|}{ Benefit Households ( $\mathrm{N}=29,367)$} \\
\hline \%Store Purchases & 0.274 & 0.310 & 0.235 & 0.153 & 0.173 & 0.133 & 0.280 & 0.318 & 0.237 & 0.473 & 0.517 & 0.422 \\
\hline Average Weekly Expenditure & 41.98 & 47.19 & 36.19 & 41.54 & 45.26 & 37.42 & 43.21 & 49.12 & 36.61 & 38.34 & 42.92 & 33.32 \\
\hline \multicolumn{13}{|l|}{ Purchased Product Quality } \\
\hline \% Generic & 0.118 & 0.116 & 0.121 & 0.098 & 0.097 & 0.099 & 0.117 & 0.116 & 0.119 & 0.131 & 0.127 & 0.136 \\
\hline \% Main & & 0.539 & 0.552 & & & 0.573 & & 0.530 & 0.546 & & & 0.551 \\
\hline$\% \mathrm{P}$ & & 0.346 & 0.327 & & & & & & 0.3 & & & 0.313 \\
\hline \%Purchases that are On sale & 0.586 & 0.582 & 0.593 & 0.579 & 0.575 & 0.583 & 0.592 & 0.587 & 0.600 & 0.580 & 0.575 & 0.587 \\
\hline \multicolumn{13}{|c|}{ Non-Benefit Households (N=229,643) } \\
\hline \%Store Purchases & 0.726 & 0.690 & 0.765 & 0.847 & 0.827 & 0.867 & 0.721 & 0.682 & 0.763 & 0.527 & 0.483 & 0.578 \\
\hline Average Weekly Expenditure & 31.23 & 31.03 & 31.43 & 33.14 & 32.88 & 33.40 & 31.62 & 31.52 & 31.72 & 24.88 & 24.47 & 25.30 \\
\hline \multicolumn{13}{|l|}{ Purchased Product Quality } \\
\hline \% Generic & 0.090 & 0.089 & 0.091 & 0.082 & 0.081 & 0.083 & 0.092 & 0.090 & 0.093 & 0.108 & 0.107 & 0.108 \\
\hline \% Mainstream & 0.569 & 0.568 & 0.570 & 0.569 & 0.567 & 0.570 & 0.569 & 0.568 & 0.570 & 0.569 & 0.569 & 0.569 \\
\hline \% Premium & 0.341 & 0.344 & 0.339 & 0.349 & 0.352 & 0.347 & 0.340 & 0.343 & 0.337 & 0.324 & 0.325 & 0.323 \\
\hline \%Purchases that are On Sale & 0.567 & 0.563 & 0.571 & 0.570 & 0.566 & 0.574 & 0.560 & 0.557 & 0.564 & 0.589 & 0.585 & 0.593 \\
\hline
\end{tabular}

Notes: A household is defined by an anonymous loyalty card identification number. Transactions from benefit households are defined as any transaction made with a loyalty card number that was used with food stamp payment method at an time during our sample period. Product quality categories were constructed from product classifications and product descriptions provided with the scanner data. On Sale items are items that registered a discount off the list price in the transaction record. 
Table 2: Change in Expenditures across Stores

\begin{tabular}{|lcccc|}
\hline & All & Store 1 & Store 2 & Store3 \\
\hline \hline Benefit Household*Week2 & $-0.2053^{* *}$ & $-0.2337^{* *}$ & $-0.1439^{* *}$ & $-0.1944^{* *}$ \\
Benefit Household*Week3 & $(0.007)$ & $(0.010)$ & $(0.015)$ & $(0.014)$ \\
& $-0.2907^{* *}$ & $-0.3167^{* *}$ & $-0.2027^{* *}$ & $-0.2853^{* *}$ \\
Benefit Household*Week4 & $(0.008)$ & $(0.010)$ & $(0.017)$ & $(0.015)$ \\
& $-0.3352^{* *}$ & $-0.3768^{* *}$ & $-0.2293^{* *}$ & $-0.3208^{* *}$ \\
Week2 & $(0.008)$ & $(0.011)$ & $(0.017)$ & $(0.015)$ \\
& $-0.0186^{* *}$ & $-0.0104^{* *}$ & $-0.0310^{* *}$ & $-0.0223^{* *}$ \\
Week3 & $(0.003)$ & $(0.004)$ & $(0.005)$ & $(0.007)$ \\
& $-0.0062^{*}$ & -0.0071 & -0.0025 & -0.0132 \\
Week4 & $(0.003)$ & $(0.004)$ & $(0.005)$ & $(0.007)$ \\
& $-0.0061^{*}$ & $-0.0147^{* *}$ & -0.0019 & 0.0087 \\
Mean Expenditures By & $(0.003)$ & $(0.004)$ & $(0.005)$ & $(0.007)$ \\
Benefit Households & & & & \\
Non-Benefit Households & 58.19 & 63.8 & 59.98 & 47.86 \\
Obs. & 30.66 & 31.13 & 32.76 & 24.56 \\
& 1398145 & 731353 & 404386 & 262406 \\
\hline
\end{tabular}

Notes: Robust standard errors in parentheses. ${ }^{*}$ significant at $5 \%$; $* *$ significant at $1 \%$. Columns present results from an OLS regression of log weekly expenditures per household and store on an indicator if the household is a benefit household, the week number in the month, and their interactions. All regressions include household fixed effects with standard errors clustered at the household level. A household is defined by an anonymous loyalty card identification number. Transactions from benefit households are defined as any transaction made with a loyalty card number that was used with food stamp payment method at any time during our sample period. Regressions pooling data from all three stores also include store-level fixed effects. 
Table 3.A: Change in Expenditures across Different Types of Goods

\begin{tabular}{|c|c|c|c|c|c|c|}
\hline \multirow[b]{2}{*}{ TYPE OF GOODS } & \multicolumn{3}{|c|}{ Benefit Household } & \multicolumn{2}{|c|}{ Mean Expenditures } & \multirow[b]{2}{*}{ Obs. } \\
\hline & Week2 & Week3 & Week4 & $\begin{array}{c}\text { Benefit } \\
\text { Household }\end{array}$ & $\begin{array}{c}\text { Non-Benefit } \\
\text { Household }\end{array}$ & \\
\hline \multicolumn{7}{|l|}{ Storable } \\
\hline Canned Fish and Meat & $\begin{array}{c}-0.0713^{* *} \\
(0.020)\end{array}$ & $\begin{array}{c}-0.1109^{* *} \\
(0.020)\end{array}$ & $\begin{array}{c}-0.1296 * * \\
(0.020)\end{array}$ & 6.49 & 5.35 & 64401 \\
\hline Canned Fruits & $\begin{array}{c}-0.0872^{* *} \\
(0.020)\end{array}$ & $\begin{array}{c}-0.1069 * * \\
(0.021)\end{array}$ & $\begin{array}{c}-0.0834 * * \\
(0.022)\end{array}$ & 4.96 & 4.01 & 61299 \\
\hline Canned Vegetables & $\begin{array}{c}-0.1225^{* *} \\
(0.018)\end{array}$ & $\begin{array}{c}-0.1413^{* *} \\
(0.019)\end{array}$ & $\begin{array}{c}-0.1621^{* *} \\
(0.019)\end{array}$ & 4.08 & 3.24 & 99489 \\
\hline Cereal and Breakfast & $\begin{array}{c}-0.1344^{* *} \\
(0.011)\end{array}$ & $\begin{array}{c}-0.1681^{* *} \\
(0.011)\end{array}$ & $\begin{array}{c}-0.1871^{* *} \\
(0.012)\end{array}$ & 12.14 & 6.47 & 205472 \\
\hline Cookies and Crackers & $\begin{array}{c}-0.0954^{* *} \\
(0.011)\end{array}$ & $\begin{array}{c}-0.1396 * * \\
(0.012)\end{array}$ & $\begin{array}{c}-0.1557^{* *} \\
(0.012)\end{array}$ & 7.33 & 4.93 & 183670 \\
\hline Flour, Sugar and Cornmeal & $\begin{array}{c}-0.1067 * * \\
(0.017)\end{array}$ & $\begin{array}{c}-0.1213 * * \\
(0.017)\end{array}$ & $\begin{array}{c}-0.1498 * * \\
(0.018)\end{array}$ & 4.68 & 3.45 & 67819 \\
\hline Frozen Breakfast Items & $\begin{array}{c}-0.0840 * * \\
(0.023)\end{array}$ & $\begin{array}{c}-0.1237^{* *} \\
(0.023)\end{array}$ & $\begin{array}{c}-0.1441^{* *} \\
(0.026)\end{array}$ & 6.62 & 4.96 & 42588 \\
\hline Frozen Fruits & $\begin{array}{c}-0.09 \\
(0.061)\end{array}$ & $\begin{array}{c}-0.0183 \\
(0.072)\end{array}$ & $\begin{array}{c}-0.1309 * \\
(0.059)\end{array}$ & 7.03 & 7.2 & 4950 \\
\hline Frozen Juices & $\begin{array}{c}-0.0700^{*} \\
(0.036)\end{array}$ & $\begin{array}{c}-0.0785^{*} \\
(0.038)\end{array}$ & $\begin{array}{c}-0.1006^{* *} \\
(0.039)\end{array}$ & 7.78 & 4.36 & 14959 \\
\hline Frozen Vegetables & $\begin{array}{c}-0.1001^{* *} \\
(0.014)\end{array}$ & $\begin{array}{c}-0.1300 * * \\
(0.015)\end{array}$ & $\begin{array}{c}-0.1512^{* *} \\
(0.015)\end{array}$ & 5.68 & 4.57 & 97640 \\
\hline Hispanic Products & $\begin{array}{c}-0.0632^{* *} \\
(0.013)\end{array}$ & $\begin{array}{c}-0.1404^{* *} \\
(0.013)\end{array}$ & $\begin{array}{c}-0.1396 * * \\
(0.013)\end{array}$ & 6.74 & 4.23 & 151746 \\
\hline Jams, Jellies and Spreads & $\begin{array}{c}-0.0757^{* *} \\
(0.019)\end{array}$ & $\begin{array}{c}-0.1184^{* *} \\
(0.019)\end{array}$ & $\begin{array}{c}-0.1269 * * \\
(0.020)\end{array}$ & 7.6 & 4.8 & 58248 \\
\hline Pasta and Pasta Sauce & $\begin{array}{c}-0.1126^{* *} \\
(0.017)\end{array}$ & $\begin{array}{c}-0.1525^{* *} \\
(0.018)\end{array}$ & $\begin{array}{c}-0.1355^{* *} \\
(0.019)\end{array}$ & 5.42 & 4.27 & 91198 \\
\hline Prep. Frozen Foods & $\begin{array}{c}-0.1452^{* *} \\
(0.011)\end{array}$ & $\begin{array}{c}-0.2036^{* *} \\
(0.012)\end{array}$ & $\begin{array}{c}-0.2336^{* *} \\
(0.012)\end{array}$ & 14.36 & 11.03 & 244537 \\
\hline Ready-To-Eat Foods & $\begin{array}{c}-0.1057 * * \\
(0.017)\end{array}$ & $\begin{array}{c}-0.1344^{* *} \\
(0.017)\end{array}$ & $\begin{array}{c}-0.1559 * * \\
(0.017)\end{array}$ & 5.21 & 3.84 & 86984 \\
\hline Rice and Beans & $\begin{array}{c}-0.1518^{* *} \\
(0.015)\end{array}$ & $\begin{array}{c}-0.2171^{* *} \\
(0.015)\end{array}$ & $\begin{array}{c}-0.2207^{* *} \\
(0.016)\end{array}$ & 6.12 & 4.23 & 117898 \\
\hline Salty Snacks & $\begin{array}{c}-0.1164^{* *} \\
(0.009)\end{array}$ & $\begin{array}{c}-0.1691^{* *} \\
(0.010)\end{array}$ & $\begin{array}{c}-0.1961^{* *} \\
(0.010)\end{array}$ & 7.71 & 4.95 & 298941 \\
\hline Shelf Juices and Drinks & $\begin{array}{c}-0.1359 * * \\
(0.014)\end{array}$ & $\begin{array}{c}-0.2011^{* *} \\
(0.015)\end{array}$ & $\begin{array}{c}-0.2107 * * \\
(0.015)\end{array}$ & 12.47 & 5.6 & 135349 \\
\hline Soups & $\begin{array}{c}-0.0825 * * \\
(0.016)\end{array}$ & $\begin{array}{c}-0.1681^{* *} \\
(0.016)\end{array}$ & $\begin{array}{c}-0.1853^{* *} \\
(0.016)\end{array}$ & 5.81 & 5.07 & 134324 \\
\hline
\end{tabular}

Notes: Robust standard errors in parentheses. ${ }^{*}$ significant at $5 \% ; * *$ significant at $1 \%$. Each row present coefficients and standard errors from a separate OLS regression of household-level log weekly expenditures for the category of food listed in each row on an indicator if the household is a benefit household, the week number in the month, and their interactions. All regressions include household fixed effects with standard errors clustered at the household level. A household is defined by an anonymous loyalty card identification number. Transactions from benefit households are defined as any transaction made with a loyalty card number that was used with food stamp payment method at any time during our sample period. Regressions pooling data from all three stores also include store-level fixed effects. 
Table 3.B: Change in Expenditures across Different Types of Goods

\begin{tabular}{|c|c|c|c|c|c|c|}
\hline \multirow[b]{2}{*}{ TYPE OF GOODS } & \multicolumn{3}{|c|}{ Benefit Household } & \multicolumn{2}{|c|}{ Mean Expenditures } & \multirow[b]{2}{*}{ Obs. } \\
\hline & Week2 & Week3 & Week4 & $\begin{array}{c}\text { Benefit } \\
\text { Household }\end{array}$ & $\begin{array}{c}\text { Non-Benefit } \\
\text { Household }\end{array}$ & \\
\hline \multicolumn{7}{|l|}{ Splurge } \\
\hline Candy, Gum and Mints & $\begin{array}{r}-0.0816^{* *} \\
(0.012)\end{array}$ & $\begin{array}{r}-0.1315^{* *} \\
(0.012)\end{array}$ & $\begin{array}{r}-0.1626^{* *} \\
(0.012)\end{array}$ & 5.71 & 3.27 & 239450 \\
\hline Sweet Baked Goods & $\begin{array}{r}-0.0903^{* *} \\
(0.016)\end{array}$ & $\begin{array}{r}-0.1457 * * \\
(0.016)\end{array}$ & $\begin{array}{r}-0.1767 * * \\
(0.017)\end{array}$ & 4.53 & 3.32 & 108863 \\
\hline Dessert and Baking Mixes & $\begin{array}{r}-0.0837^{* *} \\
(0.020)\end{array}$ & $\begin{array}{r}-0.1504^{* *} \\
(0.020)\end{array}$ & $\begin{array}{r}-0.1222^{* *} \\
(0.022)\end{array}$ & 5.53 & 4.4 & 79352 \\
\hline Desserts & $\begin{array}{r}-0.0896 * * \\
(0.025)\end{array}$ & $\begin{array}{r}-0.1026^{* *} \\
(0.025)\end{array}$ & $\begin{array}{r}-0.1053^{* *} \\
(0.026)\end{array}$ & 4.26 & 3.52 & 42730 \\
\hline Frozen Desserts, etc. & $\begin{array}{r}-0.0697 * \\
(0.032)\end{array}$ & $\begin{array}{r}-0.1020^{* *} \\
(0.035)\end{array}$ & $\begin{array}{r}-0.1096 * * \\
(0.035)\end{array}$ & 7.08 & 5.51 & 29386 \\
\hline Ice Cream & $\begin{array}{r}-0.0792 * * \\
(0.009)\end{array}$ & $\begin{array}{r}-0.1028^{* *} \\
(0.009)\end{array}$ & $\begin{array}{r}-0.1231^{* *} \\
(0.009)\end{array}$ & 8.51 & 6.36 & 195178 \\
\hline In-Store Sweet Baked Goods & $\begin{array}{r}-0.0750^{* *} \\
(0.019)\end{array}$ & $\begin{array}{r}-0.0983^{* *} \\
(0.019)\end{array}$ & $\begin{array}{r}-0.1185^{* *} \\
(0.019)\end{array}$ & 15.89 & 6.17 & 122097 \\
\hline Soft Beverages & $\begin{array}{r}-0.1155^{* *} \\
(0.008)\end{array}$ & $\begin{array}{r}-0.1778 * * \\
(0.008)\end{array}$ & $\begin{array}{r}-0.2153^{* *} \\
(0.008)\end{array}$ & 11.52 & 7.38 & 656587 \\
\hline \multicolumn{7}{|l|}{ Perishable } \\
\hline Cheese & $\begin{array}{c}-0.1073^{* *} \\
(0.010)\end{array}$ & $\begin{array}{c}-0.1487 * * \\
(0.010)\end{array}$ & $\begin{array}{c}-0.1737 * * \\
(0.011)\end{array}$ & 9.84 & 5.64 & 233186 \\
\hline Fresh Bread & $\begin{array}{r}-0.1044^{* *} \\
(0.007)\end{array}$ & $\begin{array}{r}-0.1457^{* *} \\
(0.008)\end{array}$ & $\begin{array}{r}-0.1743^{* *} \\
(0.008)\end{array}$ & 4.39 & 3.44 & 373012 \\
\hline Fresh Produce & $\begin{array}{r}-0.1020^{* *} \\
(0.009)\end{array}$ & $\begin{array}{r}-0.1571^{* *} \\
(0.009)\end{array}$ & $\begin{array}{r}-0.1670^{* *} \\
(0.010)\end{array}$ & 12.31 & 8.56 & 608458 \\
\hline In-Store Fresh Bead & $\begin{array}{r}-0.0295^{*} \\
(0.013)\end{array}$ & $\begin{array}{r}-0.0555^{* *} \\
(0.014)\end{array}$ & $\begin{array}{r}-0.0578^{* *} \\
(0.015)\end{array}$ & 6.09 & 2.61 & 130119 \\
\hline Meat & $\begin{array}{r}-0.2032^{* *} \\
(0.009)\end{array}$ & $\begin{array}{r}-0.2469 * * \\
(0.010)\end{array}$ & $\begin{array}{r}-0.2864^{* *} \\
(0.010)\end{array}$ & 20.32 & 13.6 & 496527 \\
\hline Ref. Dairy & $\begin{array}{r}-0.0843^{* *} \\
(0.006)\end{array}$ & $\begin{array}{r}-0.1253^{* *} \\
(0.007)\end{array}$ & $\begin{array}{r}-0.1434^{* *} \\
(0.007)\end{array}$ & 9.71 & 5.15 & 535028 \\
\hline Ref. Foods & $\begin{array}{r}-0.0913^{* *} \\
(0.009)\end{array}$ & $\begin{array}{r}-0.1494 * * \\
(0.010)\end{array}$ & $\begin{array}{r}-0.1643^{* *} \\
(0.010)\end{array}$ & 6.93 & 4.22 & 283029 \\
\hline Ref. Juice and Drinks & $\begin{array}{r}-0.0883^{* *} \\
(0.009)\end{array}$ & $\begin{array}{r}-0.1211^{* *} \\
(0.010)\end{array}$ & $\begin{array}{r}-0.1463^{* *} \\
(0.010)\end{array}$ & 5.74 & 4.3 & 197585 \\
\hline Seafood & $\begin{array}{r}-0.1122 * * \\
(0.021)\end{array}$ & $\begin{array}{r}-0.1661^{* *} \\
(0.021)\end{array}$ & $\begin{array}{r}-0.1292^{* *} \\
(0.023)\end{array}$ & 14.07 & 10.2 & 67482 \\
\hline \multicolumn{7}{|l|}{ Not Covered } \\
\hline Alcoholic Beverages & $\begin{array}{r}-0.0509 * * \\
(0.013)\end{array}$ & $\begin{array}{r}-0.0813 * * \\
(0.013)\end{array}$ & $\begin{array}{r}-0.0925^{* *} \\
(0.014)\end{array}$ & 36.09 & 18.47 & 218771 \\
\hline Tobacco and Smoking & $\begin{array}{r}-0.0506^{*} \\
(0.022)\end{array}$ & $\begin{array}{r}-0.0764 * * \\
(0.023)\end{array}$ & $\begin{array}{r}-0.0828 * * \\
(0.023)\end{array}$ & 26.66 & 8.64 & 41422 \\
\hline
\end{tabular}

Notes: Robust standard errors in parentheses. * significant at $5 \%$; $* *$ significant at $1 \%$. Each row present coefficients and standard errors from a separate OLS regression of household-level log weekly expenditures for the category of food listed in each row on an indicator if the household is a benefit household, the week number in the month, and their interactions. All regressions include household fixed effects with standard errors clustered at the household level. A household is defined by an anonymous loyalty card identification number. Transactions from benefit households are defined as any transaction made with a loyalty card number that was used with food stamp payment method at any time during our sample period. Regressions pooling data from all three stores also include store-level fixed effects. 
Table 4: Expenditures Patterns, All Stores, with Income Interactions

\begin{tabular}{|c|c|c|c|c|}
\hline & \multicolumn{2}{|c|}{$\begin{array}{c}\text { Base Model for } \\
\text { Subsample with Income }\end{array}$} & \multicolumn{2}{|c|}{$\begin{array}{l}\text { Interactions with } \\
\text { Income Quartiles }\end{array}$} \\
\hline & Coeff. & St. Error & Coeff. & St. Error \\
\hline \multicolumn{5}{|l|}{ Benefit Households } \\
\hline Week 2 & $-0.1864 * *$ & $(0.012)$ & $-0.2105 * *$ & $(0.011)$ \\
\hline Week 3 & $-0.2599 * *$ & $(0.013)$ & $-0.2726 * *$ & $(0.012)$ \\
\hline Week 4 & $-0.2927 * *$ & $(0.014)$ & $-0.3008 * *$ & $(0.013)$ \\
\hline \multicolumn{5}{|l|}{ Non-benefit Households } \\
\hline Week 2 & $-0.0241 * *$ & $(0.005)$ & -- & -- \\
\hline Week 3 & $-0.0127 * *$ & $(0.005)$ & -- & -- \\
\hline Week 4 & -0.008 & $(0.005)$ & -- & -- \\
\hline Week 2 *Income Quartile 1 & -- & -- & $-0.0232 * *$ & $(0.007)$ \\
\hline Week $3 *$ Income Quartile 1 & -- & -- & $-0.0199 * *$ & $(0.006)$ \\
\hline Week 4 *Income Quartile 1 & -- & -- & $-0.0176 * *$ & $(0.007)$ \\
\hline Week 2 *Income Quartile 2 & -- & -- & $-0.0345 * *$ & $(0.010)$ \\
\hline Week 3 *Income Quartile 2 & -- & -- & -0.009 & $(0.010)$ \\
\hline Week 4 *Income Quartile 2 & -- & -- & 0.002 & $(0.010)$ \\
\hline Week 2 *Income Quartile 3 & -- & -- & -0.017 & $(0.011)$ \\
\hline Week 3 *Income Quartile 3 & -- & -- & 0.000 & $(0.011)$ \\
\hline Week 4 *Income Quartile 3 & -- & -- & -0.001 & $(0.011)$ \\
\hline Week 2 *Income Quartile 4 & -- & -- & -0.018 & $(0.014)$ \\
\hline Week 3 *Income Quartile 4 & -- & -- & -0.008 & $(0.014)$ \\
\hline Week 4 *Income Quartile 4 & -- & -- & 0.001 & $(0.014)$ \\
\hline Observations & \multicolumn{2}{|l|}{571602} & & \\
\hline R-squared & \multicolumn{2}{|l|}{0.45} & & \\
\hline Mean NetAmt & \multicolumn{2}{|l|}{34.08} & & \\
\hline Mean NetAmt Welfare HH & \multicolumn{2}{|l|}{40.18} & & \\
\hline Mean NetAmt Non-Welfare HH & \multicolumn{2}{|l|}{32.3} & & \\
\hline
\end{tabular}

Notes: Robust standard errors in parentheses. * significant at 5\%; ** significant at 1\%. Columns present coefficients and standard errors from OLS regressions of household-level log weekly expenditures on the independent variables listed in each row. All regressions include household fixed effects with standard errors clustered at the household level. Household income is defined based on the retailer's demographic data for loyalty card holders. Approximately $40 \%$ of the observations in our scanner data had income information present in the demographic data. Quartiles of the income distribution are defined using the retailer demographic data for club card holders purchasing from a representative subsample of the retailer's stores. The cut-points for the first 3 quartiles are $\$ 37,000,68,000$, and 116,000 . The income information is top-coded at $\$ 500,000$. Earners in the first quartile have income levels similar to those of benefit recipient households. The categories are not additive, implying that the coefficients in column 3 give the effect of each successive week on the expenditures for people in each of 5 categories: benefit households, non-benefit households with income in quartile 1, non-benefit households with income in quartile 2, etc. 
Table 5: Decomposition of Total Expenditure Changes: Weeks 1 to 4, Benefit Households

\begin{tabular}{|c|c|c|c|c|c|}
\hline \multicolumn{2}{|c|}{ TYPE OF GOODS } & $\begin{array}{c}\text { Change in } \\
\text { Total } \\
\text { Expenditure }\end{array}$ & $\begin{array}{c}\text { Change in } \\
\text { Expenditures } \\
\text { on Extensive } \\
\text { Margin }\end{array}$ & $\begin{array}{c}\text { Change in } \\
\text { Expenditures } \\
\text { on Intensive } \\
\text { Margin }\end{array}$ & $\begin{array}{c}\text { Change in } \\
\text { Intensive/Change } \\
\text { in Total }\end{array}$ \\
\hline \multicolumn{2}{|c|}{$\overline{\text { All goods }}$} & -13.648 & -3.625 & -8.839 & 0.648 \\
\hline \multirow[t]{19}{*}{ Storable } & Canned Fish and Meat & -0.329 & -0.241 & -0.061 & 0.184 \\
\hline & Canned Fruits & -0.198 & -0.133 & -0.041 & 0.206 \\
\hline & Canned Vegetables & -0.246 & -0.158 & -0.055 & 0.225 \\
\hline & Cereal and Breakfast & -0.911 & -0.634 & -0.194 & 0.213 \\
\hline & Cookies and Crackers & -0.500 & -0.375 & -0.089 & 0.178 \\
\hline & Flour, Sugar, Cornmeal & -0.212 & -0.146 & -0.039 & 0.186 \\
\hline & Frozen Breakfast Items & -0.394 & -0.268 & -0.075 & 0.190 \\
\hline & Frozen Fruits & -0.114 & -0.105 & 0.004 & -0.036 \\
\hline & Frozen Juices & -0.203 & -0.151 & -0.032 & 0.156 \\
\hline & Frozen Vegetables & -0.430 & -0.296 & -0.091 & 0.213 \\
\hline & Hispanic Products & -0.425 & -0.330 & -0.067 & 0.158 \\
\hline & Jams, Jellies, Spreads & -0.287 & -0.206 & -0.046 & 0.160 \\
\hline & Pasta and Pasta Sauce & -0.284 & -0.199 & -0.058 & 0.206 \\
\hline & Prep. Frozen Foods & -1.863 & -1.196 & -0.473 & 0.254 \\
\hline & Ready-To-Eat Foods & -0.353 & -0.241 & -0.077 & 0.217 \\
\hline & Rice and Beans & -0.534 & -0.299 & -0.154 & 0.289 \\
\hline & Salty Snacks & -0.739 & -0.510 & -0.170 & 0.230 \\
\hline & Shelf Juices and Drinks & -0.489 & -0.368 & -0.089 & 0.182 \\
\hline & Soups & -0.368 & -0.238 & -0.086 & 0.235 \\
\hline \multirow[t]{9}{*}{ Splurge } & Candy, Gum and Mints & -0.361 & -0.278 & -0.075 & 0.208 \\
\hline & Sweet Baked Goods & -0.387 & -0.255 & -0.110 & 0.285 \\
\hline & Dessert, Baking Mixes & -0.191 & -0.151 & -0.025 & 0.131 \\
\hline & Desserts & -0.146 & -0.116 & -0.015 & 0.105 \\
\hline & Frozen Desserts, etc. & -0.157 & -0.116 & -0.027 & 0.170 \\
\hline & Ice Cream & -0.609 & -0.502 & -0.080 & 0.131 \\
\hline & In-Store Sweet Baked & & & & \\
\hline & Goods & -0.351 & -0.290 & -0.047 & 0.135 \\
\hline & Soft Beverages & -1.256 & -0.935 & -0.273 & 0.217 \\
\hline \multirow[t]{9}{*}{ Perishable } & Cheese & -0.727 & -0.534 & -0.128 & 0.176 \\
\hline & Fresh Bread & -0.290 & -0.189 & -0.076 & 0.262 \\
\hline & Fresh Produce & -1.270 & -0.924 & -0.263 & 0.207 \\
\hline & In-Store Fresh Bead & -0.120 & -0.118 & -0.004 & 0.303 \\
\hline & Meat & -4.091 & -2.200 & -1.301 & 0.318 \\
\hline & Ref. Dairy & -0.739 & -0.572 & -0.141 & 0.191 \\
\hline & Ref. Foods & -0.526 & -0.356 & -0.122 & 0.232 \\
\hline & Ref. Juice and Drinks & -0.380 & -0.300 & -0.064 & 0.168 \\
\hline & Seafood & -0.856 & -0.652 & -0.107 & 0.125 \\
\hline \multirow[t]{2}{*}{ Not Covered } & Alcoholic Beverages & -0.663 & -0.778 & 0.084 & -0.127 \\
\hline & Tobacco and Smoking & -0.240 & -0.211 & -0.023 & 0.096 \\
\hline
\end{tabular}

Notes: Let $\mathrm{E}(\mathrm{y})$ be the expected value of expenditures, $\mathrm{E}\left(\mathrm{y}^{*}\right)$ be the expected value of expenditures conditional on $\mathrm{y}$ being greater than zero and $\mathrm{F}(\mathrm{z})$ be the probability that $\mathrm{y}$ is greater than zero. Column 1 gives $\mathrm{dEy} / \mathrm{dx}$ calculated as $\mathrm{F}(\mathrm{z}) \mathrm{dEy} * / \mathrm{dx}+\mathrm{Ey} *(\mathrm{dF}(\mathrm{z}) / \mathrm{dx}$. Column 2 and 3 decompose this total derivative into changes on the extensive $\left(\mathrm{Ey}^{*}(\mathrm{dF}(\mathrm{z}) / \mathrm{dx})\right.$ and intensive $($ as $\mathrm{F}(\mathrm{z}) \mathrm{dEy} * / \mathrm{dx})$ margins respectively.

Columns 2 and 3 may not sum to 1 because of rounding. 
Table 6: Change in Quantity (in ounces) Purchases across Stores

\begin{tabular}{|lcccc|}
\hline & All & Store 1 & Store 2 & Store3 \\
\hline Benefit Household*Week2 & $-0.2386^{* *}$ & $-0.2807^{* *}$ & $-0.1537^{* *}$ & $-0.2214^{* *}$ \\
& $(0.010)$ & $(0.014)$ & $(0.020)$ & $(0.020)$ \\
Benefit Household*Week3 & $-0.3198^{* *}$ & $-0.3472^{* *}$ & $-0.2447^{* *}$ & $-0.3102^{* *}$ \\
& $(0.010)$ & $(0.014)$ & $(0.020)$ & $(0.020)$ \\
Benefit Household*Week4 & $-0.3479^{* *}$ & $-0.4091^{* *}$ & $-0.2257^{* *}$ & $-0.3275^{* *}$ \\
& $(0.011)$ & $(0.015)$ & $(0.021)$ & $(0.021)$ \\
Week2 & $-0.0173^{* *}$ & -0.0104 & $-0.0315^{* *}$ & -0.0096 \\
& $(0.004)$ & $(0.006)$ & $(0.011)$ & $(0.011)$ \\
Week3 & $0.0198^{* *}$ & 0.0091 & $0.0268^{* *}$ & $0.0344^{* *}$ \\
Week4 & $(0.004)$ & $(0.006)$ & $(0.011)$ & $(0.011)$ \\
Mean Qty. Oz. Purchased By & 0.0053 & -0.0088 & 0.0036 & $0.0496^{* *}$ \\
Benefit Households & $(0.004)$ & $(0.006)$ & $(0.011)$ & $(0.011)$ \\
Non-Benefit Households & 252.61 & & & \\
Obs. & 135.06 & 135.05 & 144.08 & 115.86 \\
& 1380582 & 722389 & 398373 & 259820 \\
\hline
\end{tabular}

Notes: Robust standard errors in parentheses. * significant at 5\%; ** significant at 1\%. Columns present OLS results from a regression of household-level log weekly quantity purchased in ounces on an indicator if the household is a benefit household, the week number in the month, and their interactions. All regressions include household fixed effects with standard errors clustered at the household level. A household is defined by an anonymous loyalty card identification number. Transactions from benefit households are defined as any transaction made with a loyalty card number that was used with food stamp payment method at any time during our sample period. Regressions pooling data from all three stores also include store-level fixed effects. 
Table 7.A: Change in Quantity (in ounces) Purchases across Different Types of Goods

\begin{tabular}{|c|c|c|c|c|c|c|}
\hline \multirow[b]{2}{*}{ TYPE OF GOODS } & \multicolumn{3}{|c|}{ Benefit Household } & \multicolumn{2}{|c|}{ Mean Qty. Oz. } & \multirow[b]{2}{*}{ Obs. } \\
\hline & Week2 & Week3 & Week4 & $\begin{array}{c}\text { Benefit } \\
\text { Household } \\
\end{array}$ & $\begin{array}{c}\text { Non-Benefit } \\
\text { Household } \\
\end{array}$ & \\
\hline \multicolumn{7}{|l|}{ Storable } \\
\hline Canned Fish and Meat & $\begin{array}{c}-0.0698^{* *} \\
(0.020)\end{array}$ & $\begin{array}{c}-0.1030 * * \\
(0.021)\end{array}$ & $\begin{array}{c}-0.1347 * * \\
(0.020)\end{array}$ & 27.81 & 21.2 & 64401 \\
\hline Canned Fruits & $\begin{array}{c}-0.0703^{* *} \\
(0.021)\end{array}$ & $\begin{array}{c}-0.0917^{* *} \\
(0.021)\end{array}$ & $\begin{array}{c}-0.0605^{* *} \\
(0.022)\end{array}$ & 52.47 & 41.81 & 61299 \\
\hline Canned Vegetables & $\begin{array}{c}-0.1237^{* *} \\
(0.019)\end{array}$ & $\begin{array}{c}-0.1394 * * \\
(0.019)\end{array}$ & $\begin{array}{c}-0.1559^{* *} \\
(0.020)\end{array}$ & 58.13 & 43.83 & 99489 \\
\hline Cereal and Breakfast & $\begin{array}{c}-0.1225^{* *} \\
(0.011)\end{array}$ & $\begin{array}{c}-0.1466^{* *} \\
(0.011)\end{array}$ & $\begin{array}{c}-0.1520 * * \\
(0.012)\end{array}$ & 58.4 & 32.18 & 205141 \\
\hline Cookies and Crackers & $\begin{array}{c}-0.0942^{* *} \\
(0.012)\end{array}$ & $\begin{array}{c}-0.1180^{* *} \\
(0.013)\end{array}$ & $\begin{array}{c}-0.1219 * * \\
(0.013)\end{array}$ & 34.33 & 21.79 & 183450 \\
\hline Flour, Sugar and Cornmeal & $\begin{array}{c}-0.1021^{* *} \\
(0.024)\end{array}$ & $\begin{array}{c}-0.1090^{* *} \\
(0.025)\end{array}$ & $\begin{array}{c}-0.1660^{* *} \\
(0.025)\end{array}$ & 111.64 & 71.17 & 65907 \\
\hline Frozen Breakfast Items & $\begin{array}{c}-0.0664^{* *} \\
(0.021)\end{array}$ & $\begin{array}{c}-0.1197^{* *} \\
(0.021)\end{array}$ & $\begin{array}{c}-0.1433^{* *} \\
(0.024)\end{array}$ & 32.94 & 24.16 & 42588 \\
\hline Frozen Fruits & $\begin{array}{c}-0.0273 \\
(0.057)\end{array}$ & $\begin{array}{l}0.0337 \\
(0.073)\end{array}$ & $\begin{array}{c}-0.1280^{*} \\
(0.059)\end{array}$ & 36.21 & 33.54 & 4950 \\
\hline Frozen Juices & $\begin{array}{l}0.0204 \\
(0.051)\end{array}$ & $\begin{array}{r}-0.0184 \\
(0.053)\end{array}$ & $\begin{array}{l}-0.007 \\
(0.050)\end{array}$ & 4.81 & 1.26 & 14959 \\
\hline Frozen Vegetables & $\begin{array}{c}-0.1004^{* *} \\
(0.015)\end{array}$ & $\begin{array}{c}-0.1120^{* *} \\
(0.016)\end{array}$ & $\begin{array}{c}-0.1242^{* *} \\
(0.016)\end{array}$ & 54.71 & 41.33 & 93469 \\
\hline Hispanic Products & $\begin{array}{c}-0.0446 \\
(0.023)\end{array}$ & $\begin{array}{c}-0.1080^{* *} \\
(0.023)\end{array}$ & $\begin{array}{c}-0.1251^{* *} \\
(0.024)\end{array}$ & 62.89 & 38.07 & 146881 \\
\hline Jams, Jellies and Spreads & $\begin{array}{c}-0.0695^{* *} \\
(0.020)\end{array}$ & $\begin{array}{c}-0.1364^{* *} \\
(0.021)\end{array}$ & $\begin{array}{c}-0.1267 * * \\
(0.022)\end{array}$ & 53.76 & 31.88 & 58216 \\
\hline Pasta and Pasta Sauce & $\begin{array}{c}-0.1150^{* *} \\
(0.017)\end{array}$ & $\begin{array}{c}-0.1537^{* *} \\
(0.018)\end{array}$ & $\begin{array}{c}-0.1380^{* *} \\
(0.018)\end{array}$ & 65.08 & 48.37 & 91198 \\
\hline Prep. Frozen Foods & $\begin{array}{c}-0.1319^{* *} \\
(0.011)\end{array}$ & $\begin{array}{c}-0.1814^{* *} \\
(0.012)\end{array}$ & $\begin{array}{c}-0.2026^{* *} \\
(0.012)\end{array}$ & 78.94 & 54.5 & 244536 \\
\hline Ready-To-Eat Foods & $\begin{array}{c}-0.1059 * * \\
(0.017)\end{array}$ & $\begin{array}{c}-0.1436 * * \\
(0.017)\end{array}$ & $\begin{array}{c}-0.1476 * * \\
(0.017)\end{array}$ & 59.69 & 44.18 & 86984 \\
\hline Rice and Beans & $\begin{array}{c}-0.1607 * * \\
(0.017)\end{array}$ & $\begin{array}{c}-0.2127 * * \\
(0.017)\end{array}$ & $\begin{array}{c}-0.2158^{* *} \\
(0.017)\end{array}$ & 47.07 & 31.12 & 117729 \\
\hline Salty Snacks & $\begin{array}{c}-0.1125^{* *} \\
(0.010)\end{array}$ & $\begin{array}{c}-0.1570^{* *} \\
(0.011)\end{array}$ & $\begin{array}{c}-0.1840^{* *} \\
(0.011)\end{array}$ & 31.38 & 20.91 & 297114 \\
\hline Shelf Juices and Drinks & $\begin{array}{c}-0.1805^{* *} \\
(0.022)\end{array}$ & $\begin{array}{c}-0.2437^{* *} \\
(0.022)\end{array}$ & $\begin{array}{c}-0.2456^{* *} \\
(0.023)\end{array}$ & 11.27 & 5.15 & 134852 \\
\hline Soups & $\begin{array}{c}-0.0785^{* *} \\
(0.020)\end{array}$ & $\begin{array}{c}-0.1243^{* *} \\
(0.020)\end{array}$ & $\begin{array}{c}-0.1518^{* *} \\
(0.020)\end{array}$ & 49.7 & 42.46 & 131819 \\
\hline
\end{tabular}

Notes: Robust standard errors in parentheses. * significant at 5\%; ** significant at $1 \%$. Each row presents OLS results from a regression of household-level log weekly quantity purchased in ounces for the food category listed in each row on an indicator if the household is a benefit household, the week number in the month, and their interactions. All regressions include household fixed effects with standard errors clustered at the household level. A household is defined by an anonymous loyalty card identification number. Transactions from benefit households are defined as any transaction made with a loyalty card number that was used with food stamp payment method at any time during our sample period. Regressions pooling data from all three stores also include store-level fixed effects. 
Table 7.B: Change in Quantity (in ounces) Purchases across Different Types of Goods

\begin{tabular}{|c|c|c|c|c|c|c|}
\hline \multirow[b]{2}{*}{ TYPE OF GOODS } & \multicolumn{3}{|c|}{ Benefit Household } & \multicolumn{2}{|c|}{ Mean Qty. Oz. } & \multirow[b]{2}{*}{ Obs. } \\
\hline & Week2 & Week3 & Week4 & $\begin{array}{c}\text { Benefit } \\
\text { Household } \\
\end{array}$ & $\begin{array}{c}\text { Non-Benefit } \\
\text { Household } \\
\end{array}$ & \\
\hline \multicolumn{7}{|l|}{ Splurge } \\
\hline Candy, Gum and Mints & $\begin{array}{c}-0.0633^{* *} \\
(0.015)\end{array}$ & $\begin{array}{c}-0.1157 * * \\
(0.016)\end{array}$ & $\begin{array}{c}-0.1510 * * \\
(0.016)\end{array}$ & 15.71 & 9.91 & 179965 \\
\hline Sweet Baked Goods & $\begin{array}{c}-0.0820^{* *} \\
(0.015)\end{array}$ & $\begin{array}{c}-0.1244^{* *} \\
(0.015)\end{array}$ & $\begin{array}{c}-0.1388^{* *} \\
(0.015)\end{array}$ & 27.83 & 17.8 & 107247 \\
\hline Dessert and Baking Mixes & $\begin{array}{c}-0.0288 \\
(0.024)\end{array}$ & $\begin{array}{c}-0.0878^{* *} \\
(0.024)\end{array}$ & $\begin{array}{c}-0.0659 * * \\
(0.025)\end{array}$ & 39.58 & 29.07 & 76710 \\
\hline Desserts & $\begin{array}{c}-0.1078 * * \\
(0.036)\end{array}$ & $\begin{array}{c}-0.0975^{* *} \\
(0.035)\end{array}$ & $\begin{array}{c}-0.1010^{* *} \\
(0.035)\end{array}$ & 23.4 & 20.03 & 35915 \\
\hline Frozen Desserts, etc. & $\begin{array}{c}-0.0327 \\
(0.036)\end{array}$ & $\begin{array}{c}-0.0879 * \\
(0.036)\end{array}$ & $\begin{array}{c}-0.0777^{*} \\
(0.036)\end{array}$ & 34.6 & 26.39 & 29386 \\
\hline Ice Cream & $\begin{array}{c}-0.0564^{* *} \\
(0.013)\end{array}$ & $\begin{array}{c}-0.0792^{* *} \\
(0.014)\end{array}$ & $\begin{array}{c}-0.1100^{* *} \\
(0.014)\end{array}$ & 2.32 & 1.75 & 194349 \\
\hline In-Store Sweet Baked Goods & $\begin{array}{c}-0.0083 \\
(0.017)\end{array}$ & $\begin{array}{r}-0.0235 \\
(0.017)\end{array}$ & $\begin{array}{c}-0.0734^{* *} \\
(0.017)\end{array}$ & 51.57 & 20 & 78234 \\
\hline Soft Beverages & $\begin{array}{c}-0.1009 * * \\
(0.009)\end{array}$ & $\begin{array}{c}-0.1544^{* *} \\
(0.009)\end{array}$ & $\begin{array}{c}-0.1697 * * \\
(0.009)\end{array}$ & 8.02 & 5.47 & 653346 \\
\hline \multicolumn{7}{|l|}{ Perishable } \\
\hline Cheese & $\begin{array}{c}-0.1047^{* *} \\
(0.011)\end{array}$ & $\begin{array}{c}-0.1465^{* *} \\
(0.011)\end{array}$ & $\begin{array}{c}-0.1663^{* *} \\
(0.012)\end{array}$ & 34.69 & 20.32 & 233186 \\
\hline Fresh Bread & $\begin{array}{c}-0.0768^{* *} \\
(0.006)\end{array}$ & $\begin{array}{c}-0.0927^{* *} \\
(0.007)\end{array}$ & $\begin{array}{c}-0.1096 * * \\
(0.007)\end{array}$ & 45.64 & 30.72 & 364352 \\
\hline Fresh Produce & $\begin{array}{c}-0.0977^{* *} \\
(0.011)\end{array}$ & $\begin{array}{c}-0.1343^{* *} \\
(0.011)\end{array}$ & $\begin{array}{c}-0.1366^{* *} \\
(0.012)\end{array}$ & 107.77 & 69.96 & 572026 \\
\hline In-Store Fresh Bead & $\begin{array}{c}-0.0279 \\
(0.021)\end{array}$ & $\begin{array}{c}-0.0311 \\
(0.020)\end{array}$ & $\begin{array}{r}-0.0209 \\
(0.020)\end{array}$ & 12.4 & 6.22 & 37942 \\
\hline Meat & $\begin{array}{c}-0.1857^{* *} \\
(0.010)\end{array}$ & $\begin{array}{c}-0.2229 * * \\
(0.010)\end{array}$ & $\begin{array}{c}-0.2482^{* *} \\
(0.010)\end{array}$ & 118.49 & 75.76 & 495781 \\
\hline Ref. Dairy & $\begin{array}{c}-0.1393^{* *} \\
(0.014)\end{array}$ & $\begin{array}{c}-0.1976^{* *} \\
(0.014)\end{array}$ & $\begin{array}{c}-0.2345^{* *} \\
(0.014)\end{array}$ & 18.17 & 14.02 & 527433 \\
\hline Ref. Foods & $\begin{array}{c}-0.0895^{* *} \\
(0.013)\end{array}$ & $\begin{array}{c}-0.1493^{* *} \\
(0.013)\end{array}$ & $\begin{array}{c}-0.1467 * * \\
(0.013)\end{array}$ & 25.52 & 16.08 & 156833 \\
\hline Ref. Juice and Drinks & $\begin{array}{c}-0.0550^{* *} \\
(0.011)\end{array}$ & $\begin{array}{c}-0.0714^{* *} \\
(0.011)\end{array}$ & $\begin{array}{c}-0.0955^{* *} \\
(0.012)\end{array}$ & 4.6 & 3.47 & 197585 \\
\hline Seafood & $\begin{array}{c}-0.1235^{* *} \\
(0.026)\end{array}$ & $\begin{array}{c}-0.1667^{* *} \\
(0.027)\end{array}$ & $\begin{array}{c}-0.1772^{* *} \\
(0.028)\end{array}$ & 38.33 & 26.44 & 67270 \\
\hline \multicolumn{7}{|l|}{ Not Covered } \\
\hline Alcoholic Beverages & $\begin{array}{c}-0.0387 * * \\
(0.014)\end{array}$ & $\begin{array}{c}-0.0684^{* *} \\
(0.014)\end{array}$ & $\begin{array}{c}-0.0887 * * \\
(0.015)\end{array}$ & 4.31 & 2.32 & 218765 \\
\hline Tobacco and Smoking & $\begin{array}{l}-0.0531 \\
(0.069) \\
\end{array}$ & $\begin{array}{l}0.0521 \\
(0.079)\end{array}$ & $\begin{array}{r}-0.0533 \\
(0.089)\end{array}$ & 0.37 & 0.05 & 1752 \\
\hline
\end{tabular}

Notes: Robust standard errors in parentheses. * significant at 5\%; ** significant at 1\%. Each row presents OLS results from a regression of household-level log weekly quantity purchased in ounces for the food category listed in each row on an indicator if the household is a benefit household, the week number in the month, and their interactions. All regressions include household fixed effects with standard errors clustered at the household level. Regressions pooling data from all three stores also include store-level fixed effects. 
Table 8: Change in Generic, Premium and On Sale Purchases across Stores

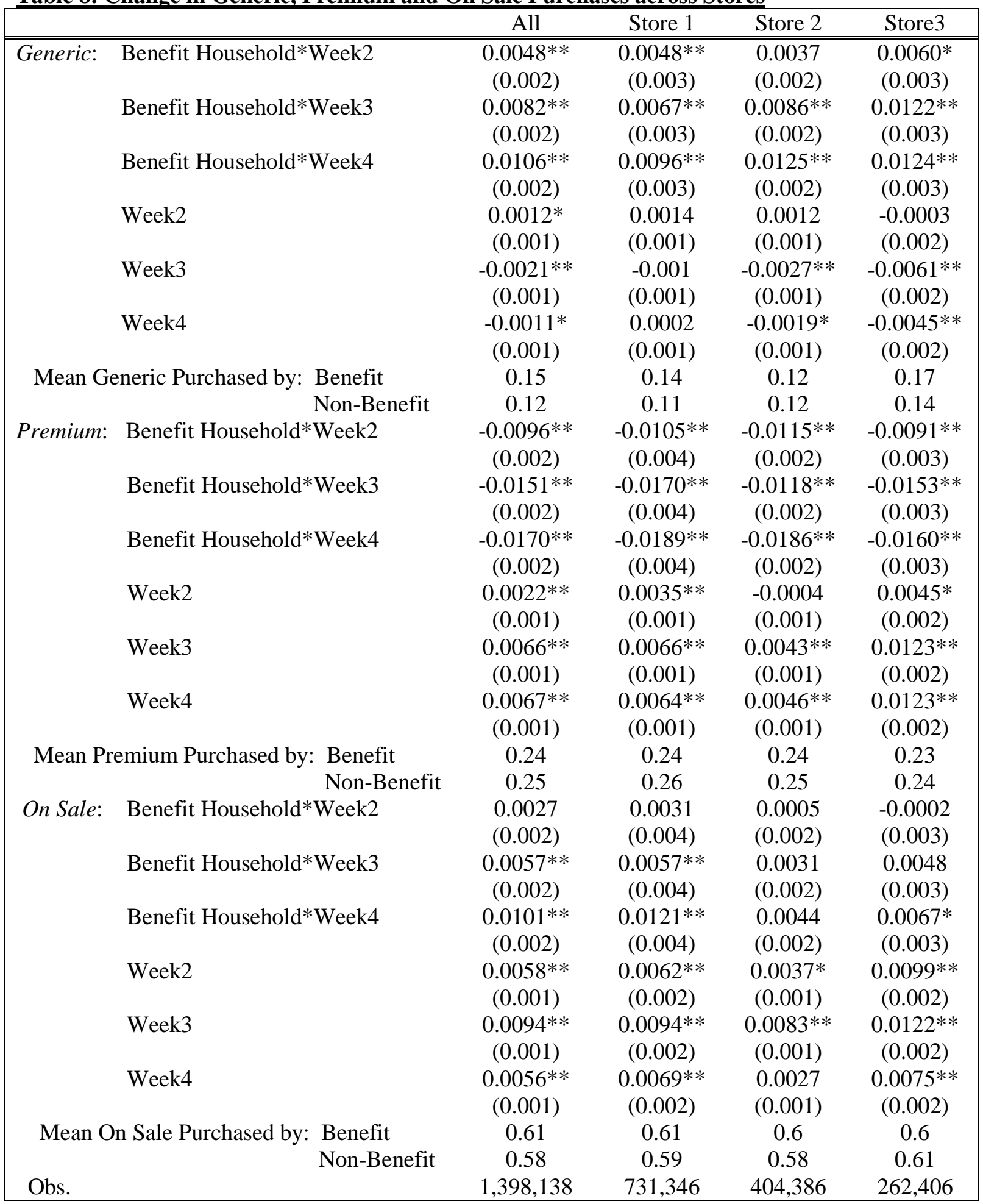

Notes: Robust standard errors in parentheses. * significant at $5 \%$; ** significant at $1 \%$. Each Panel presents results from an OLS regression of fraction of weekly purchases (standardized weight) from Generic, Premium or On Sale items on weekly dummies and their interactions with an indicator if the household is a benefit household. All specifications include household fixed-effects as well as store-level fixed-effects. Standard Errors are clustered at the household level. Product categories for Generic and Premium were created based on the categorization made by the retailer and the product names. 
Table 9.A: Change in Purchases of Generic Products, Only Significant Food Groups Presented

\begin{tabular}{|c|c|c|c|c|c|c|}
\hline \multirow[b]{2}{*}{ TYPE OF GOODS } & \multicolumn{3}{|c|}{ Benefit Household } & \multicolumn{2}{|c|}{ Mean Generic Purchases } & \multirow[b]{2}{*}{ Obs. } \\
\hline & Week2 & Week3 & Week4 & $\begin{array}{c}\text { Benefit } \\
\text { Household }\end{array}$ & $\begin{array}{c}\text { Non-Benefit } \\
\text { Household }\end{array}$ & \\
\hline \multicolumn{7}{|l|}{ Storable } \\
\hline Cereal and Breakfast & $\begin{array}{l}0.0054 \\
(0.004)\end{array}$ & $\begin{array}{c}0.0140^{* *} \\
(0.004)\end{array}$ & $\begin{array}{c}0.0234^{* *} \\
(0.004)\end{array}$ & 0.16 & 0.12 & 205472 \\
\hline Cookies and Crackers & $\begin{array}{l}0.0089 \\
(0.005)\end{array}$ & $\begin{array}{c}0.0131^{*} \\
(0.005)\end{array}$ & $\begin{array}{c}0.0170^{* *} \\
(0.005)\end{array}$ & 0.2 & 0.14 & 183670 \\
\hline Rice and Beans & $\begin{array}{c}0.012 \\
(0.007)\end{array}$ & $\begin{array}{c}0.0203^{* *} \\
(0.007)\end{array}$ & $\begin{array}{c}0.0137^{*} \\
(0.007)\end{array}$ & 0.22 & 0.18 & 117898 \\
\hline Soups & $\begin{array}{l}0.0087 \\
(0.006)\end{array}$ & $\begin{array}{c}0.0133^{*} \\
(0.006)\end{array}$ & $\begin{array}{c}0.0145^{*} \\
(0.006)\end{array}$ & 0.16 & 0.16 & 134324 \\
\hline \multicolumn{7}{|l|}{ Splurge } \\
\hline Soft Beverages & $\begin{array}{c}0.0133^{* *} \\
(0.002)\end{array}$ & $\begin{array}{c}0.0211^{* *} \\
(0.002)\end{array}$ & $\begin{array}{c}0.0179 * * \\
(0.002)\end{array}$ & 0.22 & 0.15 & 656587 \\
\hline \multicolumn{7}{|l|}{ Perishable } \\
\hline Cheese & $\begin{array}{l}0.0076 \\
(0.006)\end{array}$ & $\begin{array}{c}0.0225^{* *} \\
(0.006)\end{array}$ & $\begin{array}{c}0.0284^{* *} \\
(0.006)\end{array}$ & 0.39 & 0.33 & 233186 \\
\hline Fresh Bread & $\begin{array}{c}-0.0086^{* *} \\
(0.003)\end{array}$ & $\begin{array}{c}-0.0119 * * \\
(0.003)\end{array}$ & $\begin{array}{c}-0.0117^{* *} \\
(0.003)\end{array}$ & 0.16 & 0.14 & 373012 \\
\hline Meat & $\begin{array}{l}0.0028 \\
(0.002)\end{array}$ & $\begin{array}{c}0.0073^{* *} \\
(0.002)\end{array}$ & $\begin{array}{c}0.0104^{* *} \\
(0.002)\end{array}$ & 0.11 & 0.08 & 496527 \\
\hline Ref. Juice and Drinks & $\begin{array}{c}0.0123^{* *} \\
(0.004)\end{array}$ & $\begin{array}{c}0.0222^{* *} \\
(0.004)\end{array}$ & $\begin{array}{c}0.0173^{* *} \\
(0.004)\end{array}$ & 0.25 & 0.11 & 197585 \\
\hline
\end{tabular}

Notes: Robust standard errors in parentheses. * significant at 5\%; ${ }^{* *}$ significant at $1 \%$. Each row presents results from an OLS regression of fraction of weekly purchases (standardized weight) from Generic items on weekly dummies and their interactions with an indicator if the household is a benefit household for the product category listed in the row heading. All specifications include household fixed-effects as well as store-level fixed-effects. Standard Errors are clustered at the household level. Product categories for Generic and Premium were created based on the categorization made by the retailer and the product names. 
Table 9.B: Change in Purchases of Premium Products, Only Significant Food Groups Presented

\begin{tabular}{|c|c|c|c|c|c|c|}
\hline \multirow[b]{2}{*}{ TYPE OF GOODS } & \multicolumn{3}{|c|}{ Benefit Household } & \multicolumn{2}{|c|}{ Mean Premium Purchases } & \multirow[b]{2}{*}{ Obs. } \\
\hline & Week2 & Week3 & Week4 & $\begin{array}{c}\text { Benefit } \\
\text { Household }\end{array}$ & $\begin{array}{c}\text { Non-Benefit } \\
\text { Household }\end{array}$ & \\
\hline \multicolumn{7}{|l|}{ Storable } \\
\hline Flour, Sugar and Cornmeal & $\begin{array}{l}0.0177 \\
(0.011)\end{array}$ & $\begin{array}{l}0.0198 \\
(0.011)\end{array}$ & $\begin{array}{c}0.0245^{*} \\
(0.011)\end{array}$ & 0.31 & 0.23 & 67819 \\
\hline Salty Snacks & $\begin{array}{c}-0.0063^{*} \\
(0.003)\end{array}$ & $\begin{array}{c}-0.0102^{* *} \\
(0.003)\end{array}$ & $\begin{array}{c}-0.0076^{*} \\
(0.003)\end{array}$ & 0.08 & 0.11 & 298941 \\
\hline \multicolumn{7}{|l|}{ Perishable } \\
\hline Fresh Bread & $\begin{array}{c}-0.0171^{* *} \\
(0.004)\end{array}$ & $\begin{array}{c}-0.0281^{* *} \\
(0.004)\end{array}$ & $\begin{array}{c}-0.0362 * * \\
(0.004)\end{array}$ & 0.39 & 0.58 & 373012 \\
\hline Meat & $\begin{array}{c}-0.0078^{*} \\
(0.004)\end{array}$ & $\begin{array}{c}-0.0127^{* *} \\
(0.004)\end{array}$ & $\begin{array}{c}-0.0294^{* *} \\
(0.004)\end{array}$ & 0.6 & 0.67 & 496527 \\
\hline Ref. Juice and Drinks & $\begin{array}{l}-0.0093 \\
(0.006)\end{array}$ & $\begin{array}{c}-0.0189 * * \\
(0.006)\end{array}$ & $\begin{array}{c}-0.0168^{* *} \\
(0.006)\end{array}$ & 0.25 & 0.44 & 197585 \\
\hline
\end{tabular}

Notes: Robust standard errors in parentheses. * significant at 5\%; ** significant at $1 \%$. Each row presents results from an OLS regression of fraction of weekly purchases (standardized weight) from Premium items on weekly dummies and their interactions with an indicator if the household is a benefit household for the product category listed in the row heading. All specifications include household fixed-effects as well as store-level fixed-effects. Standard Errors are clustered at the household level. Product categories for Generic and Premium were created based on the categorization made by the retailer and the product names. 
Table 9.C: Change in Purchases of On Sale Products, Only Significant Food Groups Presented

\begin{tabular}{|c|c|c|c|c|c|c|}
\hline \multirow[b]{2}{*}{ TYPE OF GOODS } & \multicolumn{3}{|c|}{ Benefit Household } & \multicolumn{2}{|c|}{ Mean On Sale Purchases } & \multirow[b]{2}{*}{ Obs. } \\
\hline & Week2 & Week3 & Week4 & $\begin{array}{c}\text { Benefit } \\
\text { Household }\end{array}$ & $\begin{array}{c}\text { Non-Benefit } \\
\text { Household }\end{array}$ & \\
\hline \multicolumn{7}{|l|}{ Storable } \\
\hline Cereal and Breakfast & $\begin{array}{l}-0.0012 \\
(0.006)\end{array}$ & $\begin{array}{l}0.0108 \\
(0.007)\end{array}$ & $\begin{array}{c}0.0183^{* *} \\
(0.007)\end{array}$ & 0.41 & 0.37 & 205472 \\
\hline Frozen Juices & $\begin{array}{l}-0.0049 \\
(0.013)\end{array}$ & $\begin{array}{c}0.0364 * * \\
(0.013)\end{array}$ & $\begin{array}{c}0.0294^{*} \\
(0.013)\end{array}$ & 0.88 & 0.93 & 14959 \\
\hline Frozen Vegetables & $\begin{array}{l}-0.0001 \\
(0.010)\end{array}$ & $\begin{array}{c}0.0412^{* *} \\
(0.010)\end{array}$ & $\begin{array}{c}0.0393 * * \\
(0.010)\end{array}$ & 0.58 & 0.54 & 97640 \\
\hline Hispanic Products & $\begin{array}{l}-0.0049 \\
(0.008)\end{array}$ & $\begin{array}{l}-0.0101 \\
(0.008)\end{array}$ & $\begin{array}{c}-0.0185^{*} \\
(0.008)\end{array}$ & 0.33 & 0.32 & 151589 \\
\hline Prep. Frozen Foods & $\begin{array}{l}0.0035 \\
(0.005)\end{array}$ & $\begin{array}{l}0.0084 \\
(0.005)\end{array}$ & $\begin{array}{c}0.0188^{* *} \\
(0.005)\end{array}$ & 0.78 & 0.77 & 244442 \\
\hline Ready-To-Eat Foods & $\begin{array}{l}0.0149 \\
(0.011)\end{array}$ & $\begin{array}{c}0.0082 \\
(0.011)\end{array}$ & $\begin{array}{c}0.0277^{* *} \\
(0.011)\end{array}$ & 0.49 & 0.46 & 86984 \\
\hline \multicolumn{7}{|l|}{ Splurge } \\
\hline In-Store Sweet Baked Goods & $\begin{array}{l}-0.0022 \\
(0.008)\end{array}$ & $\begin{array}{l}0.0115 \\
(0.008)\end{array}$ & $\begin{array}{c}0.0257^{* *} \\
(0.008)\end{array}$ & 0.19 & 0.21 & 122097 \\
\hline Soft Beverages & $\begin{array}{c}0.001 \\
(0.003)\end{array}$ & $\begin{array}{c}0.0080^{*} \\
(0.003)\end{array}$ & $\begin{array}{c}0.0170^{* * *} \\
(0.003)\end{array}$ & 0.72 & 0.7 & 656587 \\
\hline \multicolumn{7}{|l|}{ Perishable } \\
\hline Fresh Bread & $\begin{array}{c}0.0160 * * \\
(0.005)\end{array}$ & $\begin{array}{c}0.0675^{* *} \\
(0.005)\end{array}$ & $\begin{array}{c}0.0782^{* *} \\
(0.005)\end{array}$ & 0.56 & 0.51 & 373012 \\
\hline In-Store Fresh Bead & $\begin{array}{l}0.0008 \\
(0.007)\end{array}$ & $\begin{array}{c}-0.0098 \\
(0.007)\end{array}$ & $\begin{array}{c}-0.0198^{* *} \\
(0.007)\end{array}$ & 0.12 & 0.12 & 130119 \\
\hline Ref. Juice and Drinks & $\begin{array}{l}-0.006 \\
(0.006)\end{array}$ & $\begin{array}{c}-0.0191^{* *} \\
(0.006)\end{array}$ & $\begin{array}{c}-0.0175^{* *} \\
(0.006)\end{array}$ & 0.62 & 0.73 & 197585 \\
\hline \multicolumn{7}{|l|}{ Not Covered } \\
\hline Alcoholic Beverages & $\begin{array}{c}-0.0134 * \\
(0.007)\end{array}$ & $\begin{array}{l}-0.0075 \\
(0.007)\end{array}$ & $\begin{array}{c}-0.0172 * * \\
(0.007)\end{array}$ & 0.54 & 0.68 & 218771 \\
\hline
\end{tabular}

Notes: Robust standard errors in parentheses. * significant at 5\%; ** significant at 1\%. Each row presents results from an OLS regression of fraction of weekly purchases (standardized weight) from On Sale items on weekly dummies and their interactions with an indicator if the household is a benefit household for the product category listed in the row heading. All specifications include household fixed-effects as well as store-level fixed-effects. Standard Errors are clustered at the household level. A product is categorized as On Sale if a discount is recorded for the product purchase in the transaction data. 
Table 10: Change in Log(Price Index) and Log (Price Index of The First Week of The Month) across Stores

\begin{tabular}{|c|c|c|c|c|c|c|c|c|}
\hline & \multicolumn{4}{|c|}{ NV High Poverty } & \multicolumn{4}{|c|}{ NV Low Poverty } \\
\hline & All & Store 1 & Store 2 & Store3 & All & Store 1 & Store 2 & Store3 \\
\hline \multicolumn{9}{|l|}{ Log.(Price Index) } \\
\hline Week2 & $\begin{array}{c}-0.0195 * * \\
(0.002)\end{array}$ & $\begin{array}{c}-0.0172 * * \\
(0.004)\end{array}$ & $\begin{array}{c}-0.0212 * * \\
(0.003)\end{array}$ & $\begin{array}{c}-0.0204 * * \\
(0.004)\end{array}$ & $\begin{array}{l}-0.0012 \\
(0.003)\end{array}$ & $\begin{array}{l}-0.0011 \\
(0.005)\end{array}$ & $\begin{array}{c}-0.0038 \\
(0.005)\end{array}$ & $\begin{array}{l}0.0014 \\
(0.005)\end{array}$ \\
\hline Week3 & $\begin{array}{c}-0.0243^{* *} \\
(0.002)\end{array}$ & $\begin{array}{c}-0.0138^{* *} \\
(0.004)\end{array}$ & $\begin{array}{c}-0.0268^{* *} \\
(0.003)\end{array}$ & $\begin{array}{c}-0.0334^{* *} \\
(0.004)\end{array}$ & $\begin{array}{l}0.0015 \\
(0.003)\end{array}$ & $\begin{array}{l}0.0021 \\
(0.005)\end{array}$ & $\begin{array}{l}-0.0005 \\
(0.005)\end{array}$ & $\begin{array}{l}0.0027 \\
(0.005)\end{array}$ \\
\hline Week4 & $\begin{array}{c}-0.0266^{* *} \\
(0.002)\end{array}$ & $\begin{array}{c}-0.0165^{* *} \\
(0.005)\end{array}$ & $\begin{array}{c}-0.0293^{* *} \\
(0.003)\end{array}$ & $\begin{array}{c}-0.0349 * * \\
(0.004)\end{array}$ & $\begin{array}{l}-0.0046 \\
(0.003)\end{array}$ & $\begin{array}{r}-0.0075 \\
(0.005)\end{array}$ & $\begin{array}{l}-0.0036 \\
(0.005)\end{array}$ & $\begin{array}{l}-0.0027 \\
(0.005)\end{array}$ \\
\hline \multicolumn{9}{|c|}{ Log.(1st Week Price Index) } \\
\hline Week2 & $\begin{array}{c}-0.0236 * * \\
(0.002)\end{array}$ & $\begin{array}{c}-0.0202 * * \\
(0.005)\end{array}$ & $\begin{array}{c}-0.0260 * * \\
(0.003)\end{array}$ & $\begin{array}{c}-0.0248^{* *} \\
(0.004)\end{array}$ & $\begin{array}{l}-0.0026 \\
(0.003)\end{array}$ & $\begin{array}{l}-0.002 \\
(0.005)\end{array}$ & $\begin{array}{l}-0.0054 \\
(0.004)\end{array}$ & $\begin{array}{l}-0.0003 \\
(0.005)\end{array}$ \\
\hline Week3 & $\begin{array}{c}-0.0301^{* *} \\
(0.002)\end{array}$ & $\begin{array}{c}-0.0175^{* *} \\
(0.005)\end{array}$ & $\begin{array}{c}-0.0335^{* *} \\
(0.003)\end{array}$ & $\begin{array}{c}-0.0404^{* *} \\
(0.004)\end{array}$ & $\begin{array}{l}-0.001 \\
(0.003)\end{array}$ & $\begin{array}{l}0.0001 \\
(0.005)\end{array}$ & $\begin{array}{l}-0.0031 \\
(0.004)\end{array}$ & $\begin{array}{l}0.0001 \\
(0.005)\end{array}$ \\
\hline Week4 & $\begin{array}{c}-0.0327 * * \\
(0.002)\end{array}$ & $\begin{array}{c}-0.0210 * * \\
(0.005)\end{array}$ & $\begin{array}{c}-0.0365^{* *} \\
(0.003)\end{array}$ & $\begin{array}{c}-0.0417 * * \\
(0.004)\end{array}$ & $\begin{array}{c}-0.0074 * * \\
(0.003)\end{array}$ & $\begin{array}{c}-0.0096 * \\
(0.005)\end{array}$ & $\begin{array}{l}-0.0068 \\
(0.004)\end{array}$ & $\begin{array}{l}-0.0057 \\
(0.005)\end{array}$ \\
\hline Obs. & 2086 & 723 & 723 & 640 & 2169 & 723 & 723 & 723 \\
\hline $\begin{array}{l}\text { \%Store Benefit } \\
\text { Purchases }\end{array}$ & 0.274 & 0.153 & 0.280 & 0.473 & 0.044 & 0.024 & 0.053 & 0.056 \\
\hline
\end{tabular}

Notes: Standard errors in parentheses, * significant at 5\%; ** significant at 1\%. Each column presents results from OLS regressions of log price index, calculated according to equation (2) in the text, on weekly dummies. Specifications that pool stores also include store-level fixed effects. 
Table 11: Results from Four Stores in States with 10-day Staggered Benefits Distribution

\begin{tabular}{|c|c|c|}
\hline & \multicolumn{2}{|c|}{ Dependent Variable: } \\
\hline & (1) & (2) \\
\hline & Log Weekly Expenditures & Log Price Index \\
\hline \multirow[t]{2}{*}{ Benefit Household*Week2 } & $0.0102 *$ & -- \\
\hline & $(0.0046)$ & -- \\
\hline \multirow[t]{2}{*}{ Benefit Household*Week3 } & $-0.1191 * *$ & -- \\
\hline & $(0.0046)$ & -- \\
\hline \multirow[t]{2}{*}{ Benefit Household*Week4 } & $-0.1667 * *$ & -- \\
\hline & $(0.0048)$ & -- \\
\hline \multirow[t]{2}{*}{ Week2 } & $-0.0261 * *$ & -0.0024 \\
\hline & $(0.0020)$ & $(0.0016)$ \\
\hline \multirow[t]{2}{*}{ Week3 } & 0.0015 & $-0.0130 * *$ \\
\hline & $(0.0020)$ & $(0.0016)$ \\
\hline \multirow[t]{2}{*}{ Week4 } & $-0.0165 * *$ & $-0.0245 * *$ \\
\hline & $(0.0020)$ & $(0.0017)$ \\
\hline \multicolumn{3}{|l|}{ Mean Expenditures By: } \\
\hline Benefit Households & 50.45 & \\
\hline Non-Benefit Households & 30.86 & \\
\hline Obs. & 2,798,917 & 2,891 \\
\hline
\end{tabular}

Notes: Robust standard errors in parentheses. * significant at 5\%; ** significant at 1\%. Data are from four stores in Colorado and California (Los Angeles County) where food stamp benefits are distributed over the first 10 days of the month. The first column present results from an OLS regression of log weekly expenditures per household and store on an indicator if the household is a benefit household, the week number in the month, and their interactions. Specification (1) includes store-level and household-level fixed effects with standard errors clustered at the household level. Specification (2) includes store-level fixed effects. A household is defined by an anonymous loyalty card identification number. Transactions from benefit households are defined as any transaction made with a loyalty card number that was used with food stamp payment method at any time during our sample period. Regressions pooling data from all three stores also include store-level fixed effects. 
Appendix Table A.1: Change in Log (Price Index) by Product Category

\begin{tabular}{|c|c|c|c|c|c|c|c|}
\hline \multirow[b]{2}{*}{ TYPE OF GOODS } & \multicolumn{2}{|c|}{ Week2 } & \multicolumn{2}{|c|}{ Week3 } & \multicolumn{2}{|c|}{ Week4 } & \multirow[b]{2}{*}{ Obs. } \\
\hline & Coeff. & Std.Err. & Coeff. & Std.Err. & Coeff. & Std.Err & \\
\hline \multicolumn{8}{|l|}{ Storable } \\
\hline Canned Fish and Meat & $-0.0108 * *$ & $(0.002)$ & $-0.0139 * *$ & $(0.002)$ & $-0.0140 * *$ & $(0.002)$ & 2086 \\
\hline Canned Fruits & $-0.0116 * *$ & $(0.002)$ & $-0.0143 * *$ & $(0.002)$ & $-0.0151 * *$ & $(0.002)$ & 2086 \\
\hline Canned Vegetables & $-0.0067 * *$ & $(0.002)$ & $-0.0040^{*}$ & $(0.002)$ & -0.0033 & $(0.002)$ & 2086 \\
\hline Cereal and Breakfast & $-0.0205^{* *}$ & $(0.005)$ & $-0.0230 * *$ & $(0.005)$ & $-0.0311 * *$ & $(0.005)$ & 2086 \\
\hline Cookies and Crackers & $-0.0193 * *$ & $(0.003)$ & $-0.0264 * *$ & $(0.003)$ & $-0.0310 * *$ & $(0.003)$ & 2086 \\
\hline Flour, Sugar and Cornmeal & $-0.0412 * *$ & $(0.008)$ & $-0.0344 * *$ & $(0.008)$ & $-0.0234 * *$ & $(0.008)$ & 2086 \\
\hline Frozen Breakfast Items & $-0.0370 * *$ & $(0.004)$ & $-0.0369 * *$ & $(0.004)$ & $-0.0440 * *$ & $(0.004)$ & 2086 \\
\hline Frozen Fruits & -0.0033 & $(0.011)$ & -0.0004 & $(0.011)$ & 0.0072 & $(0.011)$ & 1743 \\
\hline Frozen Juices & 0.0027 & $(0.004)$ & 0.0048 & $(0.004)$ & 0.0079 & $(0.004)$ & 2044 \\
\hline Frozen Vegetables & $-0.0273 * *$ & (0.003) & $-0.0342 * *$ & $(0.003)$ & $-0.0389 * *$ & (0.003) & 2086 \\
\hline Hispanic Products & $-0.0234 * *$ & $(0.003)$ & $-0.0223 * *$ & $(0.003)$ & $-0.0259 * *$ & (0.003) & 2086 \\
\hline Jams, Jellies and Spreads & $-0.0246 * *$ & (0.004) & $-0.0265 * *$ & $(0.004)$ & $-0.0228 * *$ & $(0.004)$ & 2086 \\
\hline Pasta and Pasta Sauce & $-0.0108 * *$ & $(0.003)$ & $-0.0169 * *$ & $(0.003)$ & $-0.0212 * *$ & $(0.003)$ & 2086 \\
\hline Prep. Frozen Foods & $-0.0397 * *$ & $(0.003)$ & $-0.0600 * *$ & $(0.003)$ & $-0.0643 * *$ & $(0.003)$ & 2086 \\
\hline o-Eat Foods & $-0.0215^{* *}$ & $(0.002)$ & $-0.0245 * *$ & $(0.002)$ & $-0.0266 * *$ & $(0.002)$ & 2086 \\
\hline Beans & $-0.0225 * *$ & $(0.003)$ & $-0.0233 * *$ & $(0.003)$ & $-0.0266 * *$ & $003)$ & 2086 \\
\hline acks & $-0.0196 * *$ & $(0.004)$ & $-0.0299 * *$ & $(0.004)$ & $-0.0307 * *$ & $(0.004)$ & 2086 \\
\hline Shelf Juices and Drinks & $-0.0186 *$ & $(0.008)$ & $-0.0227 * *$ & $(0.008)$ & $-0.0148 *$ & $(0.008)$ & 2086 \\
\hline Soups & -0.0056 & $(0.004)$ & -0.004 & $(0.004)$ & $-0.0102 * *$ & (0.004) & 2086 \\
\hline \multicolumn{8}{|l|}{ Splurge } \\
\hline Candy, & -0.0048 & & $-0.0066^{*}$ & & $83 * *$ & & 2086 \\
\hline Sweet Baked Goods & $-0.0159 * *$ & $(0.004)$ & $-0.0166 * *$ & $(0.004)$ & $-0.0257 * *$ & $04)$ & 2085 \\
\hline Dessert and Baking Mixes & -0.0039 & $(0.002)$ & $-0.0050 *$ & $(0.002)$ & $-0.0049 *$ & $(0.002)$ & 2086 \\
\hline Desserts & $-0.0041^{*}$ & $(0.002)$ & $-0.0073 * *$ & $(0.002)$ & $-0.0088 * *$ & $(0.002)$ & 2086 \\
\hline Frozen Desserts, etc. & $-0.0386 * *$ & $(0.007)$ & $-0.0355 * *$ & $(0.007)$ & $-0.0356 * *$ & $(0.007)$ & 2086 \\
\hline Ice Cre & $-0.0242 * *$ & $(0.005)$ & $-0.0369 * *$ & & $-0.0376 * *$ & $(0.005)$ & 2086 \\
\hline Sweet Baked Goods & -0.0021 & $(0.005)$ & -0.0094 & $(0.005)$ & $-0.0128 *$ & $(0.005)$ & 2083 \\
\hline Soft Beverages & -0.0047 & $(0.003)$ & $-0.0109 * *$ & $(0.003)$ & $-0.0209 * *$ & $(0.003)$ & 2086 \\
\hline \multicolumn{8}{|l|}{ Perishable } \\
\hline & $-0.0267 * *$ & & $-0.0254 * *$ & & $-0.0246 * *$ & & 2086 \\
\hline & $-0.0122 * *$ & & $-0.0312 * *$ & & $56 * *$ & 03) & 2086 \\
\hline Fresh Produce & 0.0024 & $(0.003)$ & -0.0043 & $(0.003)$ & $-0.0130 * *$ & (0.003) & 2086 \\
\hline In-Store Fresh Bead & -0.0015 & $(0.003)$ & -0.0015 & $(0.003)$ & -0.0029 & (0.003) & 2080 \\
\hline & $-0.0427 * *$ & $(0.005)$ & $-0.0491 * *$ & $(0.005)$ & $-0.0487 * *$ & $(0.005)$ & 2086 \\
\hline Ref. Dairy & $-0.0149 *$ & $(0.007)$ & $-0.0174 *$ & $(0.007)$ & $-0.0150 *$ & $(0.007)$ & 2086 \\
\hline Ref. Foods & -0.0128 & $(0.008)$ & -0.0094 & $(0.008)$ & -0.013 & (0.008) & 2086 \\
\hline Ref. Juice and Drinks & $-0.0187 * *$ & $(0.004)$ & $-0.0185 * *$ & $(0.004)$ & $-0.0216 * *$ & $(0.004)$ & 2086 \\
\hline Seafood & $-0.0458 * *$ & $(0.008)$ & $-0.0634 * *$ & $(0.008)$ & $-0.0699 * *$ & $(0.008)$ & 2086 \\
\hline \multicolumn{8}{|l|}{ Not Covered } \\
\hline Alcoholic Beverages & $-0.0217^{*}$ & $(0.009)$ & -0.0161 & $(0.009)$ & -0.0079 & $(0.009)$ & 2086 \\
\hline Tobacco and Smoking & -0.0042 & $(0.005)$ & -0.0034 & $(0.005)$ & $-0.0150 * *$ & $(0.005)$ & 2086 \\
\hline
\end{tabular}




\begin{tabular}{|c|c|c|c|c|c|c|c|}
\hline \multirow[b]{2}{*}{ TYPE OF GOODS } & \multicolumn{2}{|c|}{ Week2 } & \multicolumn{2}{|c|}{ Week3 } & \multicolumn{2}{|c|}{ Week4 } & \multirow[b]{2}{*}{ Obs. } \\
\hline & Coeff. & $\begin{array}{c}\text { Std. } \\
\text { Error }\end{array}$ & Coeff. & $\begin{array}{c}\text { Std. } \\
\text { Error }\end{array}$ & Coeff. & $\begin{array}{c}\text { Std. } \\
\text { Error }\end{array}$ & \\
\hline \multicolumn{8}{|l|}{ Storable } \\
\hline Canned Fish and Meat & $-0.0115^{* *}$ & $(0.002)$ & $-0.0149 * *$ & $(0.002)$ & $-0.0154 * *$ & $(0.002)$ & 2086 \\
\hline Canned Fruits & $-0.0132 * *$ & $(0.002)$ & $-0.0168 * *$ & $(0.002)$ & $-0.0168 * *$ & $(0.002)$ & 2086 \\
\hline Canned Vegetables & $-0.0059 * *$ & $(0.002)$ & -0.003 & $(0.002)$ & -0.0018 & $(0.002)$ & 2086 \\
\hline Cereal and Breakfast & $-0.0262 * *$ & $(0.005)$ & $-0.0306 * *$ & $(0.005)$ & $-0.0388 * *$ & $(0.005)$ & 2086 \\
\hline Cookies and Crackers & $-0.0207 * *$ & $(0.003)$ & $-0.0278 * *$ & $(0.003)$ & $-0.0333 * *$ & $(0.003)$ & 2086 \\
\hline Flour, Sugar and Cornmeal & $-0.0452 * *$ & $(0.009)$ & $-0.0381 * *$ & $(0.009)$ & $-0.0274 * *$ & $(0.009)$ & 2086 \\
\hline Frozen Breakfast Items & $-0.0385 * *$ & $(0.004)$ & $-0.0405 * *$ & $(0.004)$ & $-0.0476 * *$ & $(0.004)$ & 2086 \\
\hline Frozen Fruits & -0.0054 & $(0.010)$ & -0.0005 & $(0.010)$ & 0.0068 & $(0.010)$ & 1743 \\
\hline Frozen Juices & 0.0005 & $(0.004)$ & 0.0022 & $(0.004)$ & 0.0042 & $(0.004)$ & 2044 \\
\hline Frozen Vegetables & $-0.0295 * *$ & $(0.004)$ & $-0.0402 * *$ & $(0.004)$ & $-0.0453^{* *}$ & $(0.004)$ & 2086 \\
\hline Hispanic Products & $-0.0256 * *$ & $(0.003)$ & $-0.0246 * *$ & $(0.003)$ & $-0.0285 * *$ & $(0.003)$ & 2086 \\
\hline Jams, Jellies and Spreads & $-0.0306 * *$ & $(0.004)$ & $-0.0326 * *$ & $(0.004)$ & $-0.0266 * *$ & $(0.004)$ & 2086 \\
\hline Pasta and Pasta Sauce & $-0.0106 * *$ & $(0.003)$ & $-0.0165^{* *}$ & $(0.003)$ & $-0.0216^{* *}$ & (0.003) & 2086 \\
\hline Prep. Frozen Foods & $-0.0451 * *$ & $(0.003)$ & $-0.0795 * *$ & $(0.003)$ & $-0.0856 * *$ & (0.004) & 2086 \\
\hline Ready-To-Eat Foods & $-0.0228 * *$ & $(0.003)$ & $-0.0258 * *$ & $(0.003)$ & $-0.0283 * *$ & $(0.003)$ & 2086 \\
\hline Rice and Beans & $-0.0228 * *$ & $(0.003)$ & $-0.0230 * *$ & $(0.003)$ & $-0.0282 * *$ & $(0.003)$ & 2086 \\
\hline Salty Snacks & $-0.0217 * *$ & $(0.004)$ & $-0.0335 * *$ & $(0.004)$ & $-0.0340 * *$ & $(0.004)$ & 2086 \\
\hline Shelf Juices and Drinks & $-0.0207 * *$ & $(0.006)$ & $-0.0246 * *$ & $(0.006)$ & $-0.0184 * *$ & $(0.006)$ & 2086 \\
\hline Soups & $-0.0075 *$ & $(0.003)$ & $-0.0069 *$ & $(0.003)$ & $-0.0121^{* *}$ & $(0.004)$ & 2086 \\
\hline \multicolumn{8}{|l|}{ Splurge } \\
\hline Candy, Gum and Mints & $-0.0063^{*}$ & $(0.003)$ & -0.001 & $(0.003)$ & -0.0017 & $(0.003)$ & 2086 \\
\hline Sweet Baked Goods & $-0.0172 * *$ & $(0.004)$ & $-0.0179 * *$ & $(0.004)$ & $-0.0275^{* *}$ & $(0.004)$ & 2085 \\
\hline Dessert and Baking Mixes & $-0.0054^{*}$ & $(0.002)$ & $-0.0066 * *$ & $(0.002)$ & $-0.0063^{* *}$ & $(0.002)$ & 2086 \\
\hline Desserts & $-0.0042 *$ & $(0.002)$ & $-0.0082 * *$ & $(0.002)$ & $-0.0100 * *$ & $(0.002)$ & 2086 \\
\hline Frozen Desserts, etc. & $-0.0429 * *$ & $(0.007)$ & $-0.0389 * *$ & $(0.007)$ & $-0.0379 * *$ & $(0.007)$ & 2086 \\
\hline Ice Cream & $-0.0268 * *$ & $(0.005)$ & $-0.0408 * *$ & $(0.005)$ & $-0.0415^{* *}$ & $(0.005)$ & 2086 \\
\hline In-Store Sweet Baked Goods & -0.0063 & $(0.005)$ & $-0.0136^{*}$ & $(0.005)$ & $-0.0169 * *$ & $(0.005)$ & 2083 \\
\hline Soft Beverages & -0.0052 & $(0.003)$ & $-0.0113^{* *}$ & $(0.003)$ & $-0.0219 * *$ & $(0.003)$ & 2086 \\
\hline \multicolumn{8}{|l|}{ Perishable } \\
\hline Cheese & $-0.0323 * *$ & $(0.005)$ & $-0.0316 * *$ & $(0.005)$ & $-0.0317 * *$ & $(0.005)$ & 2086 \\
\hline Fresh Bread & $-0.0117 * *$ & $(0.003)$ & $-0.0303 * *$ & $(0.003)$ & $-0.0354 * *$ & $(0.003)$ & 2086 \\
\hline Fresh Produce & 0.0023 & $(0.003)$ & -0.0044 & $(0.003)$ & $-0.0143^{* *}$ & $(0.003)$ & 2086 \\
\hline In-Store Fresh Bead & -0.002 & $(0.003)$ & -0.0022 & $(0.003)$ & -0.0035 & $(0.003)$ & 2080 \\
\hline Meat & $-0.0494 * *$ & $(0.006)$ & $-0.0578 * *$ & $(0.006)$ & $-0.0570 * *$ & $(0.006)$ & 2086 \\
\hline Ref. Dairy & $-0.0147^{*}$ & $(0.007)$ & $-0.0171 * *$ & $(0.007)$ & $-0.0155^{*}$ & $(0.007)$ & 2086 \\
\hline Ref. Foods & -0.0142 & $(0.008)$ & -0.0113 & $(0.008)$ & -0.0147 & $(0.008)$ & 2086 \\
\hline Ref. Juice and Drinks & $-0.0198 * *$ & $(0.004)$ & $-0.0207 * *$ & $(0.004)$ & $-0.0237 * *$ & $(0.004)$ & 2086 \\
\hline Seafood & $-0.0512 * *$ & $(0.008)$ & $-0.0696 * *$ & $(0.008)$ & $-0.0756^{* *}$ & (0.008) & 2086 \\
\hline \multicolumn{8}{|l|}{ Not Covered } \\
\hline Alcoholic Beverages & $-0.0264 * *$ & $(0.009)$ & $-0.0202 *$ & $(0.009)$ & -0.0117 & (0.009) & 2086 \\
\hline Tobacco and Smoking & -0.005 & $(0.005)$ & -0.0048 & $(0.005)$ & $-0.0166 * *$ & $(0.006)$ & 2086 \\
\hline
\end{tabular}

